\title{
The Effectiveness and Safety of Heat Sensitive Moxibustion for Anaphylactic Rhinitis: A PRISMA Compliance Systematic Review and Meta- Analysis of Randomized Clinical Trials
}

Jun Yang

Jiangxi University of Traditional Chinese Medicine https://orcid.org/0000-0002-2804-2267

Jun Xiong ( $\square$ xiongjun196071@163.com )

The Affiliated Hospital of Jiangxi University of TCM

Ting Yuan

Jiangxi University of TCM

Xue Wang

Jiangxi University of TCM

Yun Feng Yunfeng

The Affiliated Hospital of Jiangxi University of TCM

Xiao hong Zhou

The Affiliated Hospital of Jiangxi University of TCM

Liao Kai

The Affiliated Hospital of Jiangxi University of TCM

Ling Ling $X u$

Jiangxia University

\section{Methodology}

Keywords: Heat sensitive moxibustion, anaphylactic rhinitis, Systematic review, Meta-analysis

Posted Date: December 17th, 2020

DOl: https://doi.org/10.21203/rs.3.rs-129187/v1

License: (9) This work is licensed under a Creative Commons Attribution 4.0 International License.

Read Full License 


\section{Abstract}

\section{Background}

Anaphylactic rhinitis (AR) is an IgE antibody-mediated, inflammatory disorder. Heat- sensitive moxibustion (HSM) has been accepted for AR in clinically. Our study was conducted to evaluate the effectiveness and safety of HSM for AR.

\section{Methods}

We conducted a comprehensive literature review of the PubMed, Cochrane Library, EMBASE, China National Knowledge Infrastructure (CNKI), Wanfang, Chinese Science and Technology Periodical Database (VIP) and Chinese Biomedical Literature Database (CBM) from their inception to April 2020 for RCTs that compared HSM with other active intervention for AR. The primary outcome measure was the total nasal symptom and sign score, and secondary outcomes include total effective rate, Rhinoconjunctivitis quality of life questionnaire (RQLQ) and adverse events. More than two authors independently conducted the process of data collection and analysis by Review Manager (Version 5.3).

Results

A total of 15 RCTs of 1087 participants were included in our study. The overall meta-analysis demonstrated that HSM were superior in relieving the symptoms and signs of AR in treatment (SMD = $-1.46,95 \% \mathrm{Cl}(-1.81,-1.10) ; \mathrm{P}<0.00001)$ or during the follow-up period $(\mathrm{SMD}=-2.87,95 \% \mathrm{Cl}(-5.11,-0.63) ; \mathrm{P}$ $<0.0001)$. The results also applied to the total effective rate $(\mathrm{OR}=2.96,95 \% \mathrm{Cl}(2.19,4.00) ; \mathrm{P}<0.00001)$ and RQLQ $(S M D=-7.80,95 \% \mathrm{Cl}(-13.92,-1.68) ; \mathrm{P}<0.00001)$ in treatment. Subgroup analysis indicated that there was a significant difference between the HSM group and control group. There were two studies referred to the adverse effects. The overall level of evidence was low with low methodology quality.

\section{Conclusion}

This meta-analysis suggests that the effectiveness of HSM on AR were statistically significant in treatment or during the follow-up period. However, the included studies have relatively poor quality; further high-quality trials should be conducted to confirm our finding.

Systematic review registration

PROSPERO CRD42019140723

\section{Background}

Anaphylactic rhinitis (AR) is an IgE antibody-mediated inflammatory disorder [1.2]. Allergen response is the characteristic pathophysiology of the AR; the most common allergens are classified as inhalation, food and chemical [3]. 
Almost one in six rhinitis patients is AR [4], a multicentric trial from 13 allergy centers in Central China had shown that $33.9 \%$ of the patients had intermittent moderate-severe AR and $53.3 \%$ persistent moderatesevere AR [5]. Those conditions not only brings a huge economic burden to the family of AR but also affects people's physical and mental health [6]. In the USA, direct health-related costs of AR are reported to increase by about 2 5 billion dollars and productivity losses by about 2 4 billion dollars a year [7]. Some studies have suggested that AR may increase the risk of anxiety, hypochondriasis or suicide [8.9].

Loratadine Tablets and inhaled budesonide are recommended for AR, while the long term use of the drug accompanied by the less effective and adverse effects such as nasal dryness and epistaxis [10.11]. Researchers found when patients accepted suspended moxibustion in clinically, they may feel one or more heat sensations (heat penetration, heat expansion, heat transmission, and nonthermal sensations) on their body [12]. Heat sensitive moxibustion (HSM), as a type of suspended moxibustion, refers to practitioners administer moxibustion on heat-sensitive acupuncture points, which are extremely sensitive to the heat stimulation of burning moxa [13].

The spectrum of disease on HSM showed that AR takes up a large proportion of respiratory system diseases [14]. On the basic theory of traditional Chinese medicine (TCM), professor Chen Rixin presents the thought of on "no allergy without any deficiency". HSM is a kind of external therapy for internal disorders, directly acting on the pathogenesis, strengthening the antipathogenic qi and removing the allergic factors [15]. It can increase blood volume, speed the blood flow, and regulate the immunologic function of the patients with AR [16]. Studies have shown that HSM could reduce the serum content of IgE and IL-4 in AR rat, and reduce allergic inflammation of nasal mucosa [17].

Some randomized controlled trials (RCTs) have reported that HSM could relieve uncomfortable symptoms and improve the life quality of AR. Review of the previous systematic review and metaanalysis, they did not provide the information about protocol and registration and without assessing the evidence quality and effect on follow-up [18]. Considering the weakness of the previous, we updated studies from seven databases and applied the scientific method to provide reliable evidence about the effectiveness and safety of HSM for AR.

\section{Methods}

\section{Protocol and registration}

Our study has been registered on PROSPERO as CRD42019140723; the protocol was available from http://dx.doi.org/10.1097/MD.0000000000018557. This study reported following the Preferred Reporting Items for Systematic Reviews and Meta-Analyses (PRISMA) guidelines [19].

\section{Information sources and search}

We searched through the database of PubMed, Cochrane Library, EMBASE, China National Knowledge Infrastructure (CNKI), Wanfang, Chinese Science and Technology Periodical Database (VIP) and Chinese 
Biomedical Literature Database (CBM) from their inception to April 2020. We also manually searched the library of Jiangxi University of traditional Chinese medicine for supplementary. The terms "allergic rhinitis", "perennial allergic rhinitis", "seasonal allergic rhinitis", "allergic rhinoconjunctivitis", "allergic rhinitis", "hay fever", "nasal allergy", "pollenosis", "pollinosis" were searched in combination with each of the following: "Heat sensitive moxibustion", "Thermal moxibustion", "Heat-sensitive Point Moxibustion", "RCT" and "randomized controlled trial". The search was restricted to studies of human participants. Search strategy can refer to Table 1, taking PubMed as an example.

\section{Literature selection and exclusion criteria}

\section{Types of Studies}

We collected RCTs of HSM for AR published in Chinese and English up to April 2020.

\section{Types of Participants}

The included participants were diagnosed under clear criteria of AR, patients with asthma, nasosinusitis, vasomotor rhinitis, infectious rhinitis, hormonal rhinitis were excluded.

\section{Types of Interventions and Comparisons}

We selected the intervention group that used HSM or HSM combined with other active therapies (e.g. conventional drugs and needling acupuncture), and the control group that chose other therapies (e.g. placebo, needling acupuncture, western drug) or the same active therapies as the intervention.

\section{Types of Outcome Measures}

The primary outcome was the total nasal symptom and sign score [20], which was measured after cessation of treatment and on three months follow time. The secondary outcomes include total effective rate (which was assessed by the total nasal symptom and sign score) [21], rhinoconjunctivitis quality of life questionnaire (RQLQ) [22] and adverse events.

\section{Study Selection}

All of the retrieved studies were managed by NoteExpress 3.0 to delete the duplicated. According to the inclusion criteria, reviewers selected the eligible through titles and abstracts, then full-text of the potential were assessed further. A researcher (JY) contacted the author to obtain information about the study as for the incomplete of the relevant data. Any divergences were settled by discussion or consulting the third one (YFJ), more than two authors independently conducted the process of study selection.

\section{Data Extraction}

Related characteristics of the included about the first author, publication year, sample, mean age/ age range, intervention, comparison, follow time were independently extracted by two reviewers ( $\mathrm{XHZ}$ and 
LLX). The data were recorded by WPS 2019; disagreements were resolved by discussion or consulting with a third review $(\mathrm{KL})$ until the agreement was accordant.

\section{Assessment of risk of bias}

We evaluated the methodological quality of the included trials by the Cochrane risk of bias tool [23]. Two reviewers (TY and XW) independently assessed the included studies; disagreements were settled by consulting with a third review (YFJ) during the process.

\section{Statistical Analysis}

Statistical analyses were performed by Review Manager (Version 5.3). Risk indices (RRs) with 95\% confidence interval $(\mathrm{Cl})$ were standardized for dichotomous outcomes; the standard mean difference (SMD) with 95\% confidence interval (Cl) was used for continuous outcomes. Heterogeneity was assessed by applying a chi-squared test. $P$ was considered to indicate a substantial level of heterogeneity. According to the heterogeneity levels of the included systematic reviews and meta-analyses, the randomeffects model $\left(R^{2} \geq 50 \%\right)$ or fixed-effects model $\left(R^{2}<50 \%\right)$ was properly selected. Subgroup analysis was conducted to identify and explain the heterogeneity. Funnel plot was used to assess publication bias.

\section{Quality of Evidence}

The GRADE approach was used to assess the quality of evidence for the main outcomes [24]. The rating included four levels: high, moderate, low, and very low, according to the quality of the evidence from five domains (limitations, inconsistency, indirectness, imprecision, and publication bias) [25]. Two reviewers (TY, XW) separately conducted the assessment process; any disagreement was resolved through discussion and consultation with a third author (JX).

\section{Results}

\section{Study Selection and Characteristics}

We obtained 93 relevant citations from seven electronic databases and manual searches. After 58 duplicate records were removed, we screened the remaining 35 records for eligibility and excluded eight records based on titles and abstracts. Full texts of the remaining 24 citations were retrieved for further assessment, and 12 records were eliminated. Finally, we included 15 RCTs and 1088 patients of AR, which were published from 2008 to 2020. The flowchart of literature selection is represented in Figure 1. We found two studies used HSM with needling acupuncture as the intervention [27.40], and seven studies used the western drug as the comparison [29.32.33.34.36.37.39]. Two researches reported the adverse event [35.39]; eight RCTs mentioned the follow time [27.28.33.35-39]. The characteristics of the included RCTs are presented in Table 2.

\section{Risk of Bias Assessments}


For the selection bias, $7(46.67 \%)$ studies specifically reported the method of random sequence generation, 4(26.67\%) studies explained proper allocation concealment by light-tight envelope [28.29.31.39]. Most articles only mentioned that they "randomly divided the participants", while they failed to provide the details of random sequence generation and allocation concealment. For blinding of participants and personnel, one research adopted moxibustion compared with the intervention [35]. Two RCTs reported blinding of outcome assessment, and the data was managed by intentional analysis [30.32]. There were no studies with selective reporting. The risk of bias of the included was shown in Figure2 and Figure3.

\section{Total Nasal Symptom and Sign Score}

\section{After cessation of treatment}

Ten RCTs of 725 participants reported the total nasal symptom and sign score after cessation of treatment [27.28.30.32-35.37-39]. The overall meta-analysis demonstrated that HSM was superior in AR, while there was substantial heterogeneity between the trials $(\mathrm{SMD}=-1.46,95 \% \mathrm{Cl}(-1.81,-1.10) ; P<$ $0.00001, P^{2}=56 \%$; Figure 4). With the purpose of finding the source of heterogeneity, random-effect model and subgroup were conducted to analysis. The subgroup meta-analysis reported that HSM was more effective for AR than the western drug (SMD $=-1.37,95 \% \mathrm{Cl}(-1.98,-0.76) ; P<0.0001, P=57 \%)$, needling acupuncture (SMD $=-1.70,95 \% \mathrm{Cl}(-3.23,-0.17) ; P=0.03, P=71 \%)$, suspended moxibustion (SMD = -1.62, $95 \% \mathrm{Cl}(-2.66,-0.58) ; P=0.002)$. The same findings applied to the comparison between HSM with needling acupuncture and needling acupuncture (SMD $=-1.38,95 \% \mathrm{Cl}(-1.49,-1.27) ; P<0.00001)$.

\section{After 3 months follow time}

Three RCTs of 220 participants reported the total nasal symptom and sign score after 3 months follow time [33.35.39]. The overall result demonstrated that HSM was more effective than the control group after 3 months follow time, while there was substantial heterogeneity between the trials $(\mathrm{SMD}=-2.87,95 \% \mathrm{Cl}$ $(-5.11,-0.63) ; P<0.0001, P^{2}=90 \%$; Figure 5). Random-effect model and subgroup were conducted to analysis further. The subgroup meta-analysis reported that HSM was more effective for AR than the western drug (SMD $\left.=-4.06,95 \% \mathrm{Cl}(-4.94,-3.19) ; P<0.00001, l^{2}=0 \%\right)$, suspended moxibustion (SMD = $-1.15,95 \% \mathrm{Cl}(-2.07,-0.23) ; P=0.01)$.

\section{Total Effective Rate}

\section{After cessation of treatment}

Fifteen RCTs of 1087 participants reported the total effective rate after cessation of treatment [26-40]. The overall meta-analysis demonstrated that HSM alone or combination of HSM with needling acupuncture and were superior in AR, and there was no significant heterogeneity among the included studies $(\mathrm{OR}=2.96,95 \% \mathrm{Cl}(2.19,4.00) ; P<0.00001, P=0 \%$; Figure 6$)$. The fixed-effect model and subgroup meta-analysis was conducted, the result showed that HSM was more effective for AR than the 
western drug $\left(\mathrm{OR}=2.79,95 \% \mathrm{Cl}(1.87,4.17) ; P<0.0001, P^{2}=57 \%\right)$, needling acupuncture $(\mathrm{OR}=2.76$, $\left.95 \% \mathrm{Cl}(1.56,4.87) ; P=0.0005, P^{2}=0 \%\right)$, suspended moxibustion (OR $=4.85,95 \% \mathrm{Cl}(1.43,16.42) ; P=$ $0.01)$. The same findings applied to the comparison between HSM with needling acupuncture and needling acupuncture $\left(\mathrm{OR}=3.62,95 \% \mathrm{Cl}\left(1.35,9.75 ; P=0.01, l^{2}=0 \%\right)\right.$.

\section{After 3 months follow time}

Six RCTs of 535 participants reported the total effective rate after 3 months follow time [28.33.35-37.39]. The overall meta-analysis demonstrated that HSM alone or combination of HSM with needling acupuncture and were superior in AR after 3 months follow time, and there was no significant heterogeneity among the included studies (OR $=5.31,95 \% \mathrm{Cl}(3.66,7.72) ; P<0.00001, \mathrm{I}^{2}=0 \%$; Figure 7). The fixed-effect model and subgroup meta-analysis was conducted, the result showed that HSM was more effective for $A R$ than the western drug $\left(\mathrm{OR}=5.63,95 \% \mathrm{Cl}(3.65,8.69) ; P<0.00001, \mathrm{I}^{2}=0 \%\right)$, needling acupuncture $(\mathrm{OR}=4.80,95 \% \mathrm{Cl}(1.45,15.94) ; P=0.01)$, suspended moxibustion $(\mathrm{OR}=4.33,95 \% \mathrm{Cl}(1.70$, 11.07); $P=0.002)$.

\section{Rhinoconjunctivitis Quality of Life Questionnaire (RQLQ)}

Four RCTs of 272 participants reported the total nasal symptom and sign score after cessation of treatment [28.32.35.39]. The overall meta-analysis demonstrated that HSM was superior in improving the life quality of AR patients, while there was substantial heterogeneity between the trials (SMD $=-7.80$, $95 \% \mathrm{Cl}(-13.92,-1.68) ; P<0.00001, P^{2}=95 \%$; Figure 8$)$. With the purpose of finding the source of heterogeneity, random-effect model and subgroup were conducted to analysis. The subgroup metaanalysis reported that HSM was more effective for AR than the western drug (SMD $=-3.93,95 \% \mathrm{Cl}(-7.24$, $-0.62) ; P=0.02)$, needling acupuncture (SMD $=-7.76,95 \% \mathrm{Cl}(-18.70,-3.17) ; P<0.00001, P=98 \%)$, suspended moxibustion $(\mathrm{SMD}=-11.75,95 \% \mathrm{Cl}(-15.65,-7.85) ; P<0.00001)$.

\section{Adverse Effects}

There were two studies referred to the adverse effects [35.39]. Xu reported one case of rash which relieved after one week on the HSM group. Zhang reported that there were no adverse effects on his research.

\section{Publication Bias}

Funnel plot based on studies on total nasal symptom and sign score and total effective rate was performed to detect the potential publication bias by RevMan5.3.0 software. The results showed that 10 studies were distributed beyond the funnel, illustrating that there may be publication bias in the total nasal symptom and sign score of HSM for AR (Figure 9). Funnel plot of 15 studies about total effective rate manifested that there was no significant asymmetry (Figure 10).

\section{Level of Evidence}


The level of evidence for three outcomes (total nasal symptom and sign score, total effective rate and RQLQ) were assessed by GRADE, which was displayed in Table 3. The results showed that the overall quality of the evidence was low, and all the outcomes were biased in allocation concealment or inadequate blinding. The outcomes of the total nasal symptom and sign score and RQLQ were imprecision which was caused by small sample sizes. The outcome of the total nasal symptom and sign score and RQLQ displayed high heterogeneity for course, treatment of the patient or different control groups. The funnel plot of the total nasal symptom and sign score and RQLQ were dissymmetrical.

\section{Discussion}

\section{Summary of Main Findings}

Our studies included 15 RCTs of 1088 patients for meta-analysis, the result showed that HSM, which was more effective than the control group. It could relive uncomfortable symptom and improve the life quality of the patients of AR. We found that it also plays a great advantage during the follow-up period. There were two studies mentioned adverse reactions, one case of rash on the treatment, which was relieved after one week. We can not draw a conclusion on the safety of HSM for the insufficient number of researches included.

The quality of the evidence was low; the outcome of the total nasal symptom and sign score and RQLQ displayed high heterogeneity. Although subgroup analysis was conducted to explore the heterogeneity of treatment effects in RCTs, heterogeneity still existed in these comparisons. Variability of duration from six to thirty and different acupoints selected might be the possible source of bias. Majority of the RCTs was limited to low methodology quality; most studies failed to provide the details of random sequence generation and allocation concealment. The lack of blinding may exaggerate the results of the outcome measures. The conclusion of the composite outcome was not very reliable.

\section{Strengths and Limitation}

Following is the summary of the present research: (1) Comprehensive search strategies were applied to relative databases to ensure that all RCTs were identified; (2) Compared to the previous studies, we provided registration and considered the level of the evidence on our study; (3) Subgroup analysis was performed based on variable comparisons, and we considered the follow-up effect of the HSM, which could ensure the credibility of our results.

There are some limitation in the present study: (1) The low quality of the included studies with a high risk of selection bias and performance bias for without providing the details of random sequence generation and allocation concealment, losing of blinding, so the results should be interpreted with caution. (2) considering the small number of studies reported the side effects; we could not assess the overall side effects of HSM for AR. (3) Due to the treatment mode and the duration of each trial were not equivalent, we could not confirm how long HSM treatment is required to achieve the best effect for AR. (4) The outcome of total nasal symptom and sign score consisted of four symptoms and one sign; we did not 
record the score of each part separately in our study, so we could not tell the symptom difference of HSM treatment.

\section{Opportunities for Future Research}

Through this review, we found that current evidence is of low quality. Thus further research is needed: (1) The primary RCTs should give more attention to allocation concealment and blinding, which could reduce the risk basis of the evidence. (2) Although there were some RCTs research to explore the efficacy of HSM, few studies concentrated on the adverse effects and laboratory examination such as IgE, IgM, IgG and so on. (3) More researches could pay more attention to the specific symptom improvement (sneezing, rhinorrhea, nasal itching and nasal obstruction) of AR for HSM, to explore the best effect of HSM on symptom improvement.

\section{Conclusion}

In conclusion, the results of this meta-analysis suggest that HSM alone or combination of HSM with needling acupuncture is more effective to relieve the symptoms and improve the life quality than the western drug, suspended moxibustion, or needling acupuncture in the treatment of AR. On the period of follow-up, the effect of HSM took more advantages over the control group. The results should be interpreted cautiously for the low quality of the evidence. There is no enough evidence to support that HSM is a safe method for AR; future studies should place more emphasis on the safety of HSM for AR. More efforts are required to improve the study quality of RCTs, and researchers should strictly adhere to the relative methodology and reporting guidelines.

\section{Abbreviations}

HSM冈heat sensitive moxibustion

AR囚anaphylactic rhinitis

RCTs: randomized controlled trials

CNKIهChina National Knowledge Infrastructure

VIP®Chinese Science and Technology Periodical Database

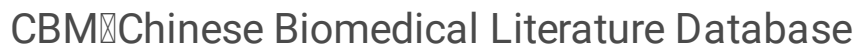

RQLQ囚rhinoconjunctivitis quality of life questionnaire

TCM: traditional Chinese medicine

PRISMA: preferred reporting items for systematic reviews and meta-analyses 


\section{Declarations}

\section{Ethics approval and consent to participate}

Not applicable.

\section{Consent for publication}

Not applicable.

\section{Availability of data and materials}

All data generated or analyzed during this study are included in this published article.

\section{Competing interests}

The authors declare that they have no competing interests.

\section{Funding}

This work was supported by Jiangxi key research and development program, China (Grant number: 20161BBG70109), Jiangxi Outstanding Young Talents Funding Scheme, China (Grant number: 20171BCB23093), Project of the National Natural Science Foundation of China (Grant number: 81573835) and Jiangxi provincial youth fund key projects, China (Grant number: 20192ACB21007). The funders had no role in study design; in the collection, analysis and interpretation of data; in the writing of the articles; and in the decision to submit it for publication.

\section{Authors' contributions}

Conceptualization: JX, JY

Data curation: TT, XW, JY, LLX, XHZ.

Formal analysis: KL, YFJ.

Investigation: YFJ, KL.

Methodology: JX

Software: XW, TY, JY.

Project administration: JX, JY.

Supervision: YFJ, JX.

Writing - original draft: JY, XW, TY. 
Writing - review \& editing: JX, YFJ.

\section{Acknowledgements}

The authors would like to thank Professor Xiong who gave methodological guidance on evidence-based medicine, and classmates for their cooperation and hard work.

\section{References}

[1]. Small M, Piercy J, Demoly P, et al., "Burdroen of illness and quality of life in patients being treated for seasonal allergic rhinitis: a cohort survey," Clin Transl Allergy, vol. 3, pp.33, 2013.

[2]. Wheatley LM, Togias A, “Clinical practice. Allergic rhinitis,” N Engl JMed, vol. 272, no. 04, pp.56-63, 2015.

[3]. Small P, Kim H, "Allergic rhinitis," Allergy Asthma Clin Immunol, vol. 7, pp.3, 2011.

[4]. Brozek JL, Bousquet J, Baena-Cagnani CE, Bonini S, Canonica GW, Casale TB, et al., "Allergic Rhinitis and its Impact on Asthma (ARIA) guidelines: 2010 revision," J Allergy Clin Immunol, vol. 126, no. 04, pp.66-76, 2010.

[5]. Chen J, Zhao Y, Li B, et al., "A multicenter study of the clinical features of allergic rhinitis in central China," American Journal of Rhinology \& Allergy, vol. 28, no. 05, pp.392-396, 2014.

[6]. Schoenwetter WF, Dupclay L Jr, Appajosyula S, Botteman MF, Pashos CL, "Economic impact and quality-of-life burden of allergic rhinitis," Curr Med Res Opin, vol. 20, pp.305-317, 2004.

[7]. Seidman MD, Gurgel RK, Lin SY, et al. "Clinical practice guideline: allergic rhinitis," Otolaryngol Head Neck Surg, vol. 152, no. 02, pp.197-206, 2015.

[8]. Sansone RA, Sansone LA, "Allergic rhinitis: relationships with anxiety and mood syndromes," Innov Clin Neurosci, vol. 88, no. 07, pp.12-7, 2011.

[9]. Qin P, Mortensen PB, Waltoft BL, Postolache TT, "Allergy is associated with suicide completion with a possible mediating role of mood disorder-a population-based study," Allergy, vol. 66, no. 05, pp.658-664, 2011.

[10]. Nickels AS, Dimov V, Wolf R, "Pharmacokinetic evaluation of olopatadine for the treatment of allergic rhinitis and conjunctivitis," Expert Opinion on Drug Metabolism \& Toxicology, vol. 7, no. 12, pp.1593-1599, 2011.

[11]. Panwankar R, Canonica GW, Holgate ST, “WHO white book on allergy: update. Milwaukee, WI: World Allergy Organization," 2013. 
[12]. Xie D, Liu Z, Hou X, et al., "Heat sensitisation in suspended moxibustion: features and clinical relevance," Acupunct Med, vol. 31, pp. 422-424, 2013.

[13]. R. Chen and M. Kang, “Clinical application of acupoint heatsensitization,” Zhongguo zhen jiu, vol. 27, no. 5, pp. 199-202, 2007 (Chinese).

[14]. Liu naigang, fang ting, zhang huifang, et al., "Study on spectrum of disease of heat-sensitive moxibustion therapy based on modern literature," Jilin Chinese medicine, vol. 38, no. 10, pp.1216-1220, 2008.

[15]. Xiong jun, Chen yan-qi, Chen ri-xin. "Professor Chen ri-xin's academic thought and clinical application of "no deficiency, no sensitivity"," Chinese acupuncture and moxibustion, vol. 40, no. 02, pp.199-202, 2020.

[16]. Cho ZH, Hwang SC, Wong EK, et al., "Neural substrates, experimental evidences and functional hypothesis of acupuncture mechanisms," Acta Neurol Scand, vol. 113, pp.370-377, 2006. 10.1111/j.16000404.2006.00600.x.

[17]. Chen panbi, XuanJin, Shi Linwei, et al., "Thermal moxibustion on allergic rhinitis rats serum IgE, the influence of the content of IL - 4," Chinese journal of modern medicine, pp.17-21, 2017.

[18]. Dong wenhua, li xiaoli, li Junxiong, tian ning, “Efficacy of heat-sensitive moxibustion in treatment of patients with allergic rhinitis: A Meta-analysis," Journal of tropical medicine, vol. 19, no. 04, pp.422-425, 2019.

[19]. Moher D, Liberati A, Tetzlaff J, Altman DG, Group P, “Preferred reporting items for systematic reviews and meta-analyses: the PRISMA statement," PLoS Med, vol. 6, no. 07, 2009:e1000097.

doi:10.1371/journal.pmed.1000097.

[20]. Pfaar O, Demoly P, Gerth van Wijk R, et al., "Recommendations for the standardization of clinical outcomes used in allergen immunotherapy trials for allergic rhinoconjunctivitis: an EAACI Position Paper," Allergy, vol. 69, 2014.

[21]. Editorial board of Chinese journal of otolaryngology and head and neck surgery, "Chinese medical association otolaryngology throat lodge. Principles of diagnosis and treatment of allergic rhinitis and recommendations," The ear, nose Journal of laryngeal head and neck surgery, vol. 40, no. 03, pp.166-167, 2005.

[22]. Dirk A. E. Dietz de Loos, Christine L. Segboer, Artur Gevorgyan, et al., "Disease-Specific Quality-of-Life Questionnaires in Rhinitis and Rhinosinusitis: Review and Evaluation," Current Allergy and Asthma Reports, vol. 13, no. 02, pp.162-170, 2013.

[23]. Julian PT Higgins Senior Statistician Visiting Fellow, and D. G. Altman, "Assessing Risk of Bias in Included Studies. Cochrane Handbook for Systematic Reviews of Interventions: Cochrane Book Series," 
John Wiley \& Sons, Ltd, 2008.

[24]. The GRADE Working Group. List of GRADE working group publications and grants. Available at: http://www.gradeworkinggroup. org/publications/index.htm.

[25]. GRADE Working GroupGrading quality of evidence and strength of recommendations. BMJ 2004;328:1490.

[26]. Cai jia, Zeng fanrong, "Clinical study on the treatment of allergic rhinitis with heat-sensitive moxibustion with yingxiang and fengchi," Journal of gannan medical college, vol. 34, no. 6, pp.942-943, 2014.

[27]. Zeng shuhua, mai yinghong, pan runyi, "Observation on the therapeutic effect of heat-sensitive moxibustion combined with acupuncture on allergic rhinitis," Journal of practical Chinese medicine, vol. 33, no. 6, pp.718, 2017.

[28]. Huang wanlin, "Clinical study on heat-sensitive moxibustion in the treatment of allergic rhinitis," Traditional Chinese Medicine University of Jiangxi, 2020.

[29]. Li hong, "Clinical observation of 18 cases of allergic rhinitis treated by thermal moxibustion," Chinese health nutrition, vol. 29, no. 25, pp.368-369, 2019.

[30]. Lin jing, "Study on the distribution of "heat sensitive points" of yangming meridian and the effect of acupuncture in patients with perennial allergic rhinitis," Traditional Chinese Medicine University of Fujian, 2015.

[31]. Lin yufen, Lu jianmin, Su yanna et al., "Clinical trials for treatment of allergic rhinitis with heatsensitive moxibustion and its regularity of heat sensitization of acupoints distribution," Acupuncture research, vol. 42, no. 06, pp.527-532, 2017.

[32]. Lin yufen, zhong zebin, su yanna, "Clinical observation of 36 cases of allergic rhinitis treated by thermal moxibustion," Journal of traditional Chinese medicine, vol. 58, no. 03, pp.235-238, 2017.

[33]. Lu min, fan xinghua, xie qiang. "Comparative observation on the therapeutic effect of heat-sensitive moxibustion and medicine on allergic rhinitis," Shanghai journal of acupuncture and moxibustion, vol. 32, no. 12, pp.1020-1021, 2013.

[34]. Xiong chengyao, Tao bo, "Observation on the curative effect of nasal acupuncture combined with thermal moxibustion in treating allergic rhinitis," World's latest medical information digest, vol. 19, no. 93, pp.171-178, 2019.

[35]. Xu lu. Effects of heat-sensitive moxibustion on symptoms and quality of life of allergic rhinitis patients. Traditional Chinese Medicine University of Guangzhou. 2016. 
[36]. Yang shurong, Chen huan, "Clinical observation of 68 cases of perennial rhinitis treated by "heat sensitive point" moxibustion," Research on ent of traditional Chinese medicine, 2008.

[37]. Yang shurong, Chen huan, Xie qiang, "Observation on therapeutic effect of moxibustion at"heat sensitive points"on perennial allergic rhinitis," Chinese Acupuncture\& Moxibustion, vol. 28, no. 02, pp.114$115,2008$.

[38]. Zhang bo, Chi zhenhai, Fu yong et al., "Clinical observation of thermal moxibustion in the treatment of allergic rhinitis," Journal of Jiangxi traditional Chinese medicine, vol. 42, no. 01, pp.59-60, 2011.

[39]. Zhang zheng, "Randomized controlled trial of the clinical efficacy of heat-sensitive moxibustion in the treatment of allergic rhinitis," Traditional Chinese Medicine University of Jiangxi, 2014.

[40]. Zhu qingyuan, Xiong jun, "Effects of heat sensitive moxibustion at acupoint combined with nose three on allergic rhinitis patients," Medical diet and health, vol. 18, no. 01, pp.40-42, 2020.

\section{Tables}

\section{Table 1:Search strategy(PubMed)}

\begin{tabular}{|c|c|}
\hline Order & Strategy \\
\hline \#1 & Search "Rhinitis, Allergic"[Mesh] \\
\hline \#2 & $\begin{array}{l}\text { Search }(((((((\text { allergic rhinitis[Title/Abstract]) OR perennial allergic rhinitis[Title/Abstract]]) OR } \\
\text { seasonal allergic rhinitis[Title/Abstract]) OR allergic rhinoconjunctivitis[Title/Abstract]) OR } \\
\text { hay fever[Title/Abstract]) OR nasal allergy[Title/Abstract]) OR pollenosis[Title/Abstract]) OR } \\
\text { pollinosis[Title/Abstract]) OR anaphylactic rhinitis[Title/Abstract] }\end{array}$ \\
\hline \#3 & \#1 OR \#2 \\
\hline \#4 & $\begin{array}{l}\text { Search }((((((\text { randomized controlled trial[Publication Type]]) OR controlled clinical } \\
\text { trial[Publication Type] }) \text { OR randomized[Title/Abstract]) OR drug therapy[MeSH Subheading]) } \\
\text { OR placebo[Title/Abstract]) OR randomly[Title/Abstract]) OR trial[Title/Abstract]) OR } \\
\text { groups[Title/Abstract] }\end{array}$ \\
\hline \#5 & Search (animals[MeSH Terms]) NOT humans[MeSH Terms] \\
\hline \#6 & \#4 NOT \#5 \\
\hline \#7 & $\begin{array}{l}\text { (((Heat-sensitive moxibustion[Title/Abstract]) OR (Thermal moxibustion[Title/Abstract])) OR } \\
\text { (Heat-sensitive Point Moxibustion[Title/Abstract]) OR (HSM[Title/Abstract]) }\end{array}$ \\
\hline \#8 & \#6 AND \#7 \\
\hline
\end{tabular}

\section{Table 2: General characteristics of included studies}




\begin{tabular}{|c|c|c|c|c|c|c|}
\hline Study & $\begin{array}{l}\text { Mean age/ } \\
\text { age range }\end{array}$ & $\begin{array}{l}\text { Sample } \\
\text { size(T/C) }\end{array}$ & $\begin{array}{l}\text { Treatment } \\
\text { group }\end{array}$ & Control group & Outcomes & $\begin{array}{l}\text { Follow } \\
\text { time }\end{array}$ \\
\hline $\begin{array}{l}\text { Cao } \\
2017 \\
{[26]}\end{array}$ & $\begin{array}{l}\mathrm{T}: 36.2 \pm 4.8 \\
\mathrm{C}: 37.1 \pm 4.6\end{array}$ & $43 / 43$ & $\begin{array}{l}\mathrm{HSM}+ \\
\text { Needling } \\
\text { Acupuncture; } \\
50 \mathrm{~min} / \mathrm{d} \text {, } \\
20 \mathrm{~d}\end{array}$ & $\begin{array}{l}\text { Needling } \\
\text { Acupuncture; } 30 \\
\text { min/d, 30d }\end{array}$ & 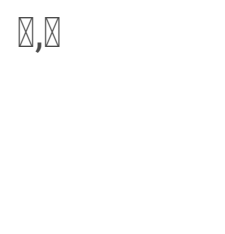 & $\begin{array}{l}3 \\
\text { months }\end{array}$ \\
\hline $\begin{array}{l}\text { Zhu } \\
2020 \\
{[27]}\end{array}$ & $\begin{array}{l}\mathrm{T}: 37.63 \pm 8.52 \\
\mathrm{C}: 37.91 \pm 8.74\end{array}$ & $40 / 40$ & $\begin{array}{l}\mathrm{HSM}+ \\
\text { Needling } \\
\text { Acupuncture; } \\
45 \mathrm{~min} / \mathrm{d} \text {, } \\
30 \mathrm{~d}\end{array}$ & $\begin{array}{l}\text { Needling } \\
\text { Acupuncture; } 25 \\
\text { min/d, 30d }\end{array}$ & 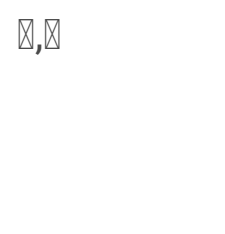 & $\begin{array}{l}\text { not } \\
\text { mention }\end{array}$ \\
\hline $\begin{array}{l}\text { Li } \\
2019 \\
{[28]}\end{array}$ & $\begin{array}{l}\mathrm{T}: 16 \sim 55 \\
\mathrm{C}: 16 \sim 55\end{array}$ & $18 / 18$ & $\begin{array}{l}\mathrm{HSM} ; 40-90 \\
\mathrm{~min} / \mathrm{d}, 20 \mathrm{~d}\end{array}$ & $\begin{array}{l}\text { Ephedrine } \\
\text { Hydrochloride and } \\
\text { Nitrofurazone } \\
\text { Nasal Drops; 3-5 } \\
\text { drops, twice daily, } \\
\text { 20d }\end{array}$ & प & $\begin{array}{l}\text { not } \\
\text { mention }\end{array}$ \\
\hline $\begin{array}{l}\operatorname{Lin} \\
2017 b \\
{[29]}\end{array}$ & $\begin{array}{l}\mathrm{T}: 26.64 \pm 5.70 \\
\mathrm{C}: 27.78 \pm 5.78\end{array}$ & $36 / 36$ & $\begin{array}{l}\mathrm{HSM} ; 40 \\
\mathrm{~min} / \mathrm{d}, 20 \mathrm{~d}\end{array}$ & $\begin{array}{l}\text { Ephedrine } \\
\text { Hydrochloride and } \\
\text { Nitrofurazone } \\
\text { Nasal Drops; 3-5 } \\
\text { drops, twice daily, } \\
\text { 20d }\end{array}$ & $\bigotimes, \bigotimes, \bigotimes$ & $\begin{array}{l}\text { not } \\
\text { mention }\end{array}$ \\
\hline $\begin{array}{l}\text { Lv } \\
2013 \\
{[30]}\end{array}$ & $\begin{array}{l}\mathrm{T}: 8 \sim 68 \\
\mathrm{C}: 7 \sim 65\end{array}$ & $40 / 40$ & 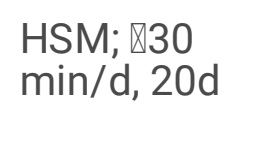 & $\begin{array}{l}\text { Budesonide nasal } \\
\text { spray; tid, 20d }\end{array}$ & 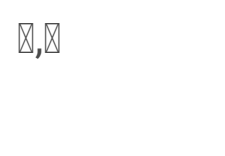 & $\begin{array}{l}3 \\
\text { months }\end{array}$ \\
\hline $\begin{array}{l}\text { Xiong } \\
2019 \\
{[31]}\end{array}$ & $\begin{array}{l}\mathrm{T}: 41.6 \pm 10.5 \\
\mathrm{C}: 41.2 \pm 12.2\end{array}$ & $30 / 30$ & $\begin{array}{l}\mathrm{HSM} ; 30 \\
\mathrm{~min} / \mathrm{d}, 21 \mathrm{~d}\end{array}$ & $\begin{array}{l}\text { Loratadine } \\
\text { Tablets; } 10 \mathrm{mg} / \mathrm{d} \text {, } \\
\text { 21d }\end{array}$ & 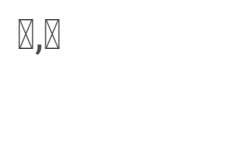 & $\begin{array}{l}\text { not } \\
\text { mention }\end{array}$ \\
\hline $\begin{array}{l}\text { Yang } \\
\text { 2008a } \\
{[32]}\end{array}$ & 33.7 & $68 / 68$ & HSM; qd, 10d & $\begin{array}{l}\text { Cetiriti } \\
\text { hydrochloride } \\
\text { tablets; } 10 \mathrm{mg} / \mathrm{d} \text {, } \\
10 \mathrm{~d}\end{array}$ & प & $\begin{array}{l}3 \\
\text { months }\end{array}$ \\
\hline $\begin{array}{l}\text { Yang } \\
2008 \mathrm{~b} \\
{[33]}\end{array}$ & $\begin{array}{l}\mathrm{T}: 15 \sim 6237.6 \\
\mathrm{C}: 14 \sim 6039.4\end{array}$ & $60 / 60$ & HSM; qd, 10d & $\begin{array}{l}\text { Cetiriti } \\
\text { hydrochloride } \\
\text { tablets; } 10 \mathrm{mg} / \mathrm{d} \text {, } \\
10 \mathrm{~d}\end{array}$ & $\mathbb{Q}, \mathbb{Q}$ & $\begin{array}{l}3 \\
\text { months }\end{array}$ \\
\hline \multirow{2}{*}{$\begin{array}{l}\text { Zhang } \\
2014 \\
\text { [34] }\end{array}$} & $\mathrm{T}: 27.33 \pm 13.21$ & \multirow[t]{2}{*}{$30 / 30$} & \multirow[t]{2}{*}{ HSM; qd, 30d } & \multirow{2}{*}{$\begin{array}{l}\text { Antihistamine } \\
\text { drug; } 30 \mathrm{~d}\end{array}$} & \multirow[t]{2}{*}{$\bigotimes, \bigotimes, \bigotimes, \bigotimes$} & \multirow{2}{*}{$\begin{array}{l}3 \\
\text { months }\end{array}$} \\
\hline & $\mathrm{C}: 28.21 \pm 14.30$ & & & & & \\
\hline $\begin{array}{l}\mathrm{Xu} \\
2016 \\
{[35]}\end{array}$ & $\begin{array}{l}\mathrm{T}: 31.85 \pm 8.66 \\
\mathrm{C}: 33.00 \pm 10.66\end{array}$ & $40 / 40$ & $\begin{array}{l}\mathrm{HSM} ; 40 \\
\mathrm{~min} / \mathrm{d}, 6 \mathrm{~d}\end{array}$ & $\begin{array}{l}\text { Suspended } \\
\text { Moxibustion; } 40 \\
\text { min/d, 6d }\end{array}$ & $\bigotimes, \bigotimes, \bigotimes, \bigotimes$ & $\begin{array}{l}3 \\
\text { months }\end{array}$ \\
\hline \multirow{2}{*}{$\begin{array}{l}\text { Huang } \\
2020 \\
{[36]}\end{array}$} & $\mathrm{T}: 29$ & \multirow[t]{2}{*}{$30 / 30$} & \multirow{2}{*}{$\begin{array}{l}\mathrm{HSM} ; 50 \\
\mathrm{~min} / \mathrm{d}, 10 \mathrm{~d}\end{array}$} & \multirow{2}{*}{$\begin{array}{l}\text { Needling } \\
\text { Acupuncture; } 30 \\
\text { min/d, 10d }\end{array}$} & \multirow[t]{2}{*}{$\mathrm{Q}, \mathrm{Q}, \mathbb{Q}$} & \multirow{2}{*}{$\begin{array}{l}3 \\
\text { months }\end{array}$} \\
\hline & C:30 & & & & & \\
\hline
\end{tabular}




\begin{tabular}{|c|c|c|c|c|c|c|}
\hline $\begin{array}{l}\text { Zhang } \\
2011 \\
\text { [37] }\end{array}$ & $\begin{array}{l}\mathrm{T}: 48.6 \pm 13.2 \\
\mathrm{C}: 49.2 \pm 15.5\end{array}$ & $30 / 30$ & $\begin{array}{l}\mathrm{HSM} ; 40-50 \\
\mathrm{~min} / \mathrm{d}, 20 \mathrm{~d}\end{array}$ & $\begin{array}{l}\text { Needling } \\
\text { Acupuncture; } 30 \\
\text { min/d, 20d }\end{array}$ & 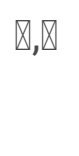 & $\begin{array}{l}3 \\
\text { months }\end{array}$ \\
\hline $\begin{array}{l}\text { Lin } \\
2017 a \\
{[38]}\end{array}$ & $\begin{array}{l}\mathrm{T}: 26.5 \pm 6.2 \\
\mathrm{C}: 27.9 \pm 6.1\end{array}$ & $35 / 35$ & $\begin{array}{l}\mathrm{HSM} ; 30-60 \\
\mathrm{~min} / \mathrm{d}, 20 \mathrm{~d}\end{array}$ & $\begin{array}{l}\text { Needling } \\
\text { Acupuncture; } 30 \\
\text { min/d, 20d }\end{array}$ & ? & $\begin{array}{l}\text { not } \\
\text { mention }\end{array}$ \\
\hline \multirow{2}{*}{$\begin{array}{l}\text { Lin } \\
2015 \\
{[39]}\end{array}$} & $\mathrm{T}: 32.00 \pm 1.67$ & \multirow[t]{2}{*}{$24 / 24$} & \multirow[t]{2}{*}{ HSM; qd, 10d } & \multirow{2}{*}{$\begin{array}{l}\text { Needling } \\
\text { Acupuncture; } 30 \\
\text { min/d, 20d }\end{array}$} & \multirow[t]{2}{*}{$\mathrm{Q}, \mathrm{Q}$} & \multirow{2}{*}{$\begin{array}{l}\text { not } \\
\text { mention }\end{array}$} \\
\hline & C:30.83 \pm 1.68 & & & & & \\
\hline $\begin{array}{l}\text { Cai } \\
2014 \\
{[40]}\end{array}$ & $\begin{array}{l}\mathrm{T}: 16 \sim 65 \\
\mathrm{C}: 16 \sim 65\end{array}$ & $20 / 20$ & $\begin{array}{l}\mathrm{HSM} ; 30-60 \\
\mathrm{~min} / \mathrm{d}, 20 \mathrm{~d}\end{array}$ & $\begin{array}{l}\text { Needling } \\
\text { Acupuncture; } 30 \\
\text { min/d, 20d }\end{array}$ & ૫ & $\begin{array}{l}\text { not } \\
\text { mention }\end{array}$ \\
\hline
\end{tabular}

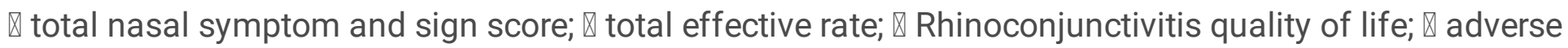
events

\section{Table 3: Level of evidence}

\begin{tabular}{|c|c|c|c|}
\hline Outcome & $\begin{array}{l}\text { Included } \\
\text { studies }\end{array}$ & Effect size & $\begin{array}{l}\text { Level of } \\
\text { Evidence }\end{array}$ \\
\hline \multirow[t]{2}{*}{$\begin{array}{l}\text { Total nasal symptom and sign score } \\
\text { (after cessation of treatment) }\end{array}$} & \multirow[t]{2}{*}{$\begin{array}{l}10 \text { RCTs, } 725 \\
\text { participants }\end{array}$} & \multirow[t]{2}{*}{$\begin{array}{l}\mathrm{SMD}=-1.46,95 \% \mathrm{Cl}(-1.81 \\
-1.10), P<0.00001, P^{2}=56 \%\end{array}$} & $\begin{array}{l}\oplus \mathbb{Q Q} \mathrm{Q}(1) \\
(2)(4)\end{array}$ \\
\hline & & & Very low \\
\hline \multirow[t]{2}{*}{$\begin{array}{l}\text { Total nasal symptom and sign score } \\
\text { (after } 3 \text { months follow time) }\end{array}$} & \multirow[t]{2}{*}{$\begin{array}{l}3 \text { RCTs, } 220 \\
\text { participants }\end{array}$} & \multirow[t]{2}{*}{$\begin{array}{l}\mathrm{SMD}=-2.87,95 \% \mathrm{Cl}(-5.11 \\
-0.63), P<0.0001, P^{2}=90 \%\end{array}$} & $\begin{array}{l}\oplus \mathbb{Q} \mathrm{Q} \otimes(1) \\
(2)(3)\end{array}$ \\
\hline & & & Very low \\
\hline \multirow{2}{*}{$\begin{array}{l}\text { Total effective rate (after cessation } \\
\text { of treatment) }\end{array}$} & \multirow{2}{*}{$\begin{array}{l}15 \mathrm{RCTs} \\
1087 \\
\text { participants }\end{array}$} & \multirow{2}{*}{$\begin{array}{l}\mathrm{OR}=2.96,95 \% \mathrm{Cl}(2.19,4.00) \\
P<0.00001, I^{2}=0 \%\end{array}$} & $\oplus \oplus \oplus \mathbb{\nabla}(1)$ \\
\hline & & & Moderate \\
\hline \multirow{2}{*}{$\begin{array}{l}\text { total effective rate (after } 3 \text { months } \\
\text { follow time) }\end{array}$} & \multirow{2}{*}{$\begin{array}{l}6 \text { RCTs, } 535 \\
\text { participants }\end{array}$} & \multirow{2}{*}{$\begin{array}{l}\mathrm{OR}=5.31,95 \% \mathrm{Cl}(3.66,7.72) \\
P<0.00001, P^{2}=0 \%\end{array}$} & $\oplus \oplus \oplus \mathbb{\nabla}(1)$ \\
\hline & & & Moderate \\
\hline \multirow[t]{2}{*}{$\begin{array}{l}\text { Rhinoconjunctivitis quality of life } \\
\text { questionnaire }\end{array}$} & \multirow[t]{2}{*}{$\begin{array}{l}4 \text { RCTs, } 272 \\
\text { participants }\end{array}$} & \multirow[t]{2}{*}{$\begin{array}{l}\mathrm{SMD}=-7.80,95 \% \mathrm{Cl}(-13.92 \\
-1.68), P<0.00001, P^{2}=95 \%\end{array}$} & $\begin{array}{l}\mathbb{R \| Q}(1)(2) \\
(3)(4)\end{array}$ \\
\hline & & & Very low \\
\hline
\end{tabular}

(1)Allocation concealment or blinding inadequate; (2) $R^{2}>50 \%$ or large heterogeneity; (3) Less sample size, wide $95 \% \mathrm{Cl}$; (4)funnel plot dissymmetry or language limitation.

\section{Figures}




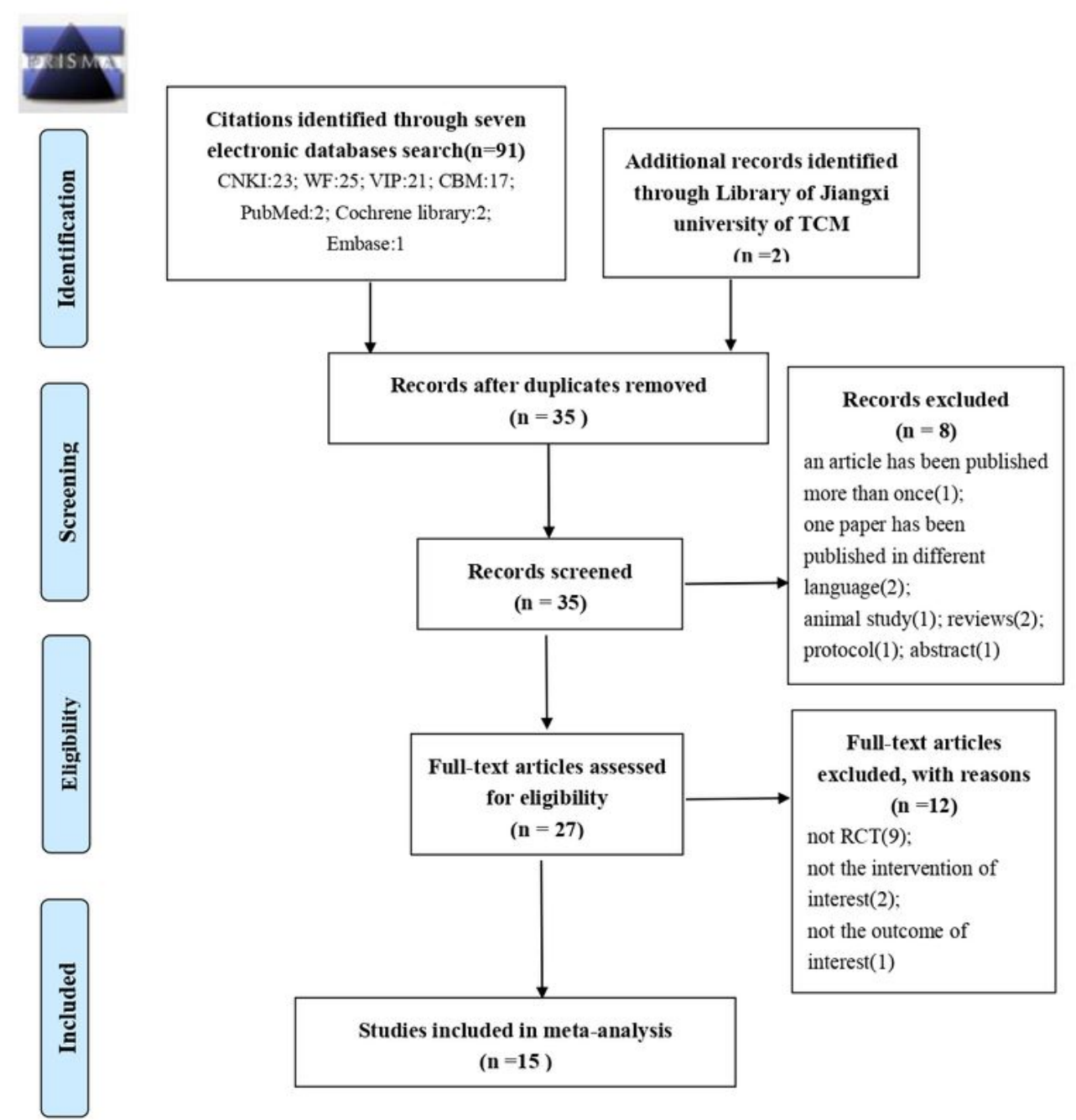

Figure. 1. Flowchart of literature selection

\section{Figure 1}

Flowchart of literature selection. 


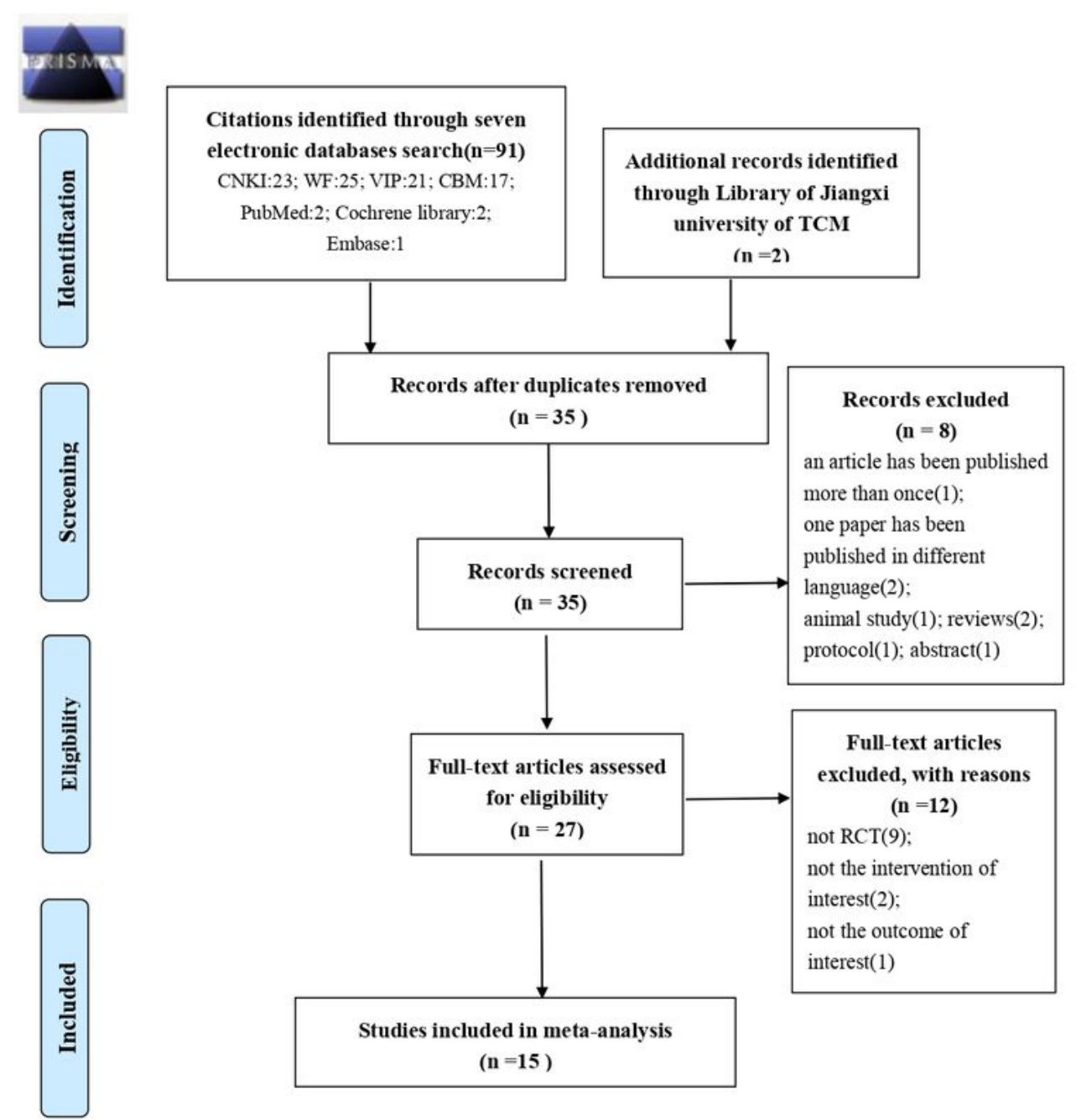

Figure. 1. Flowchart of literature selection

\section{Figure 1}

Flowchart of literature selection. 


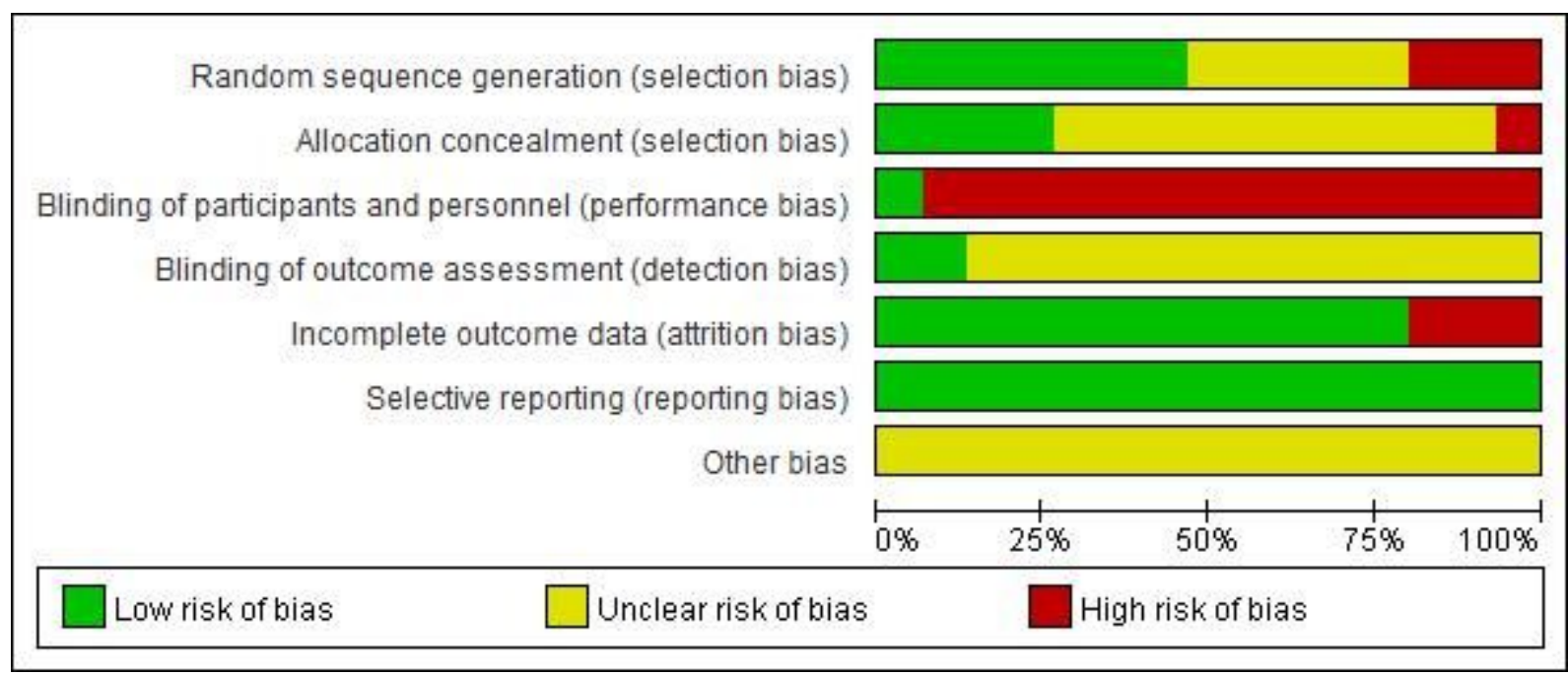

Figure 2

Risk of bias graph.

\begin{tabular}{|c|c|c|c|c|c|c|c|c|c|c|c|c|c|c|c|}
\hline $\begin{array}{l}\text { N } \\
\text { ㄹ } \\
\text { N } \\
\text { N } \\
\end{array}$ & $\begin{array}{l}\frac{N}{\vec{N}} \\
\frac{D}{\vec{D}} \\
\stackrel{N}{0} \\
\stackrel{D}{\vec{D}}\end{array}$ & 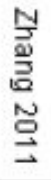 & 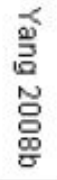 & 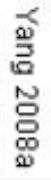 & 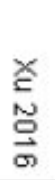 & 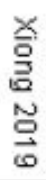 & 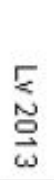 & 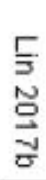 & 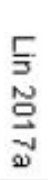 & $\begin{array}{l}\text { 肎 } \\
\stackrel{\mathrm{N}}{\overrightarrow{\mathrm{G}}}\end{array}$ & 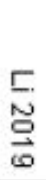 & 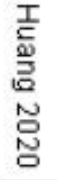 & 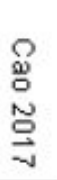 & 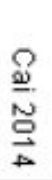 & \\
\hline+ & + & & + & $\sim$ & & $\sim$ & & + & + & $\sim$ & + & + & $\cdot v$ & $\cdot$ & Random sequence generation (selection bias) \\
\hline$\cdot v$ & 4 & $\sim$ & 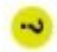 & $\cdot$ & & $-\nu$ & $-\nu$ & + & $\cdot \omega$ & $\sim$ & + & + & $\cdot \omega$ & $\cdot$ & Allocation concealment (selection bias) \\
\hline & & & & & & & & & & & & & & & Blinding of participants and personnel (performance bias) \\
\hline$\cdot \omega$ & $\omega$ & $\omega$ & $\omega$ & $\cdot v$ & $\cdot v$ & $\omega$ & $\omega$ & $\sim \omega$ & & + & $\omega$ & $\cdot v$ & 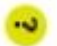 & $\cdot \omega$ & Blinding of outcome assessment (detection bias) \\
\hline+ & + & + & + & + & + & + & + & + & & & & & + & & Incomplete outcome data (attrition bias) \\
\hline+ & + & + & + & + & + & + & + & + & + & + & + & + & + & + & Selective reporting (reporting bias) \\
\hline$\cdot v$ & $\sim$ & $-v$ & $\omega$ & $\cdot v$ & $\cdot v$ & $-\omega$ & $\omega$ & $\cdot v$ & $\cdot v$ & $\omega$ & $\omega$ & $\sim$ & $\cdot \omega$ & $-\omega$ & Other bias \\
\hline
\end{tabular}

Figure 3

Risk of bias summary. 


\begin{tabular}{|c|c|c|c|c|c|c|c|c|c|c|c|c|c|c|c|}
\hline $\begin{array}{l}\text { N } \\
\stackrel{2}{\Sigma} \\
\text { N } \\
\text { N } \\
\end{array}$ & 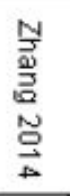 & 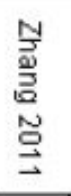 & 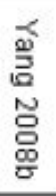 & 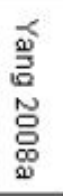 & $\begin{array}{l}\text { 希 } \\
\text { No } \\
\text { 劣 }\end{array}$ & 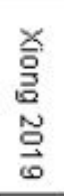 & $\begin{array}{l}\underset{\Sigma}{N} \\
\stackrel{\Xi}{\omega}\end{array}$ & $\begin{array}{l}\text { 동 } \\
\text { 号 } \\
\text { 김 }\end{array}$ & 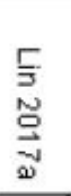 & $\begin{array}{l}\stackrel{5}{\Xi} \\
\stackrel{N}{\circ} \\
\stackrel{\vec{G}}{\vec{G}}\end{array}$ & $\begin{array}{l}\text { 동 } \\
\text { 음 }\end{array}$ & 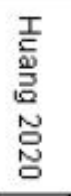 & 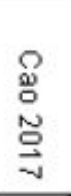 & 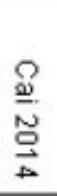 & \\
\hline$\odot$ & $\odot$ & 0 & $\odot$ & $\sim$ & (P) & $\sim$ & 0 & $\odot$ & $\odot$ & $\sim$ & $\odot$ & $\odot$ & $\sim$ & $\sim$ & Random sequence generation (selection bias) \\
\hline$\cdot$ & $\odot$ & $\sim$ & $\sim$ & $\sim$ & P & $\sim$ & $\sim$ & $\odot$ & $\sim$ & $\sim$ & $\odot$ & $\odot$ & $\cdot$ & $\sim$ & Allocation concealment (selection bias) \\
\hline (1) & ( & P & ○ & P & $\odot$ & (1) & ? & 0 & & (1) & (1) & P & O & ○ & Blinding of participants and personnel (performance bias) \\
\hline$\sim$ & $\sim$ & $\sim$ & $\sim$ & $\sim$ & $\sim$ & $\sim$ & $\sim$ & $\sim$ & $\odot$ & 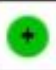 & $\sim$ & $\sim$ & $\cdot$ & $\sim$ & Blinding of outcome assessment (detection bias) \\
\hline$\odot$ & $\odot$ & $\odot$ & $\odot$ & $\odot$ & $\odot$ & $\odot$ & $\odot$ & $\odot$ & P & (?) & $\odot$ & P & $\odot$ & $\odot$ & Incomplete outcome data (attrition bias) \\
\hline+ & $\odot$ & 4 & + & 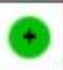 & $\odot$ & 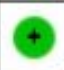 & $\odot$ & $\odot$ & 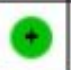 & $\odot$ & $\odot$ & 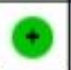 & $\odot$ & $\odot$ & Selective reporting (reporting bias) \\
\hline$\sim$ & $-v$ & $\omega$ & $\sim$ & $\cdot v$ & $\sim$ & $\sim$ & $\nu$ & $\sim$ & $\cdot$ & $\nu$ & $\nu$ & $\nu$ & $\cdot v$ & 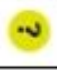 & Other bias \\
\hline
\end{tabular}

Figure 3

Risk of bias summary.

\begin{tabular}{|l} 
Random sequence generation (selection bias) \\
Allocation concealment (selection bias) \\
Blinding of participants and personnel (performance bias) \\
Blinding of outcome assessment (detection bias) \\
Incomplete outcome data (attrition bias) \\
Selective reporting (reporting bias) \\
Other bias \\
\end{tabular}

Figure 3

Risk of bias graph. 


\begin{tabular}{|c|c|c|c|c|c|c|c|c|c|c|c|c|c|c|c|}
\hline $\begin{array}{l}\text { N } \\
\stackrel{2}{\Sigma} \\
\text { N } \\
\text { N } \\
\end{array}$ & 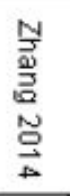 & 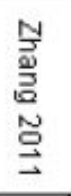 & 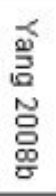 & 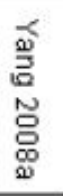 & $\begin{array}{l}\text { 希 } \\
\text { No } \\
\text { 劣 }\end{array}$ & 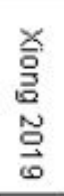 & $\begin{array}{l}\underset{\Sigma}{N} \\
\stackrel{\Xi}{\omega}\end{array}$ & $\begin{array}{l}\text { 동 } \\
\text { 号 } \\
\text { 김 }\end{array}$ & 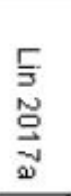 & $\begin{array}{l}\stackrel{5}{\Xi} \\
\stackrel{N}{\circ} \\
\stackrel{\vec{G}}{\vec{G}}\end{array}$ & $\begin{array}{l}\text { 동 } \\
\text { 음 }\end{array}$ & 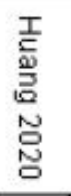 & 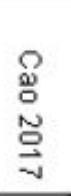 & 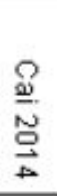 & \\
\hline$\odot$ & $\odot$ & 0 & $\odot$ & $\sim$ & (P) & $\sim$ & 0 & $\odot$ & $\odot$ & $\sim$ & $\odot$ & $\odot$ & $\sim$ & $\sim$ & Random sequence generation (selection bias) \\
\hline$\cdot$ & $\odot$ & $\sim$ & $\sim$ & $\sim$ & P & $\sim$ & $\sim$ & $\odot$ & $\sim$ & $\sim$ & $\odot$ & $\odot$ & $\cdot$ & $\sim$ & Allocation concealment (selection bias) \\
\hline (1) & ( & P & ○ & P & $\odot$ & (1) & ? & 0 & & (1) & (1) & P & O & ○ & Blinding of participants and personnel (performance bias) \\
\hline$\sim$ & $\sim$ & $\sim$ & $\sim$ & $\sim$ & $\sim$ & $\sim$ & $\sim$ & $\sim$ & $\odot$ & 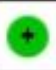 & $\sim$ & $\sim$ & $\cdot$ & $\sim$ & Blinding of outcome assessment (detection bias) \\
\hline$\odot$ & $\odot$ & $\odot$ & $\odot$ & $\odot$ & $\odot$ & $\odot$ & $\odot$ & $\odot$ & P & (?) & $\odot$ & P & $\odot$ & $\odot$ & Incomplete outcome data (attrition bias) \\
\hline+ & $\odot$ & 4 & + & 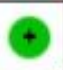 & $\odot$ & 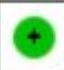 & $\odot$ & $\odot$ & 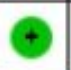 & $\odot$ & $\odot$ & 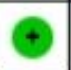 & $\odot$ & $\odot$ & Selective reporting (reporting bias) \\
\hline$\sim$ & $-v$ & $\omega$ & $\sim$ & $\cdot v$ & $\sim$ & $\sim$ & $\nu$ & $\sim$ & $\cdot$ & $\nu$ & $\nu$ & $\nu$ & $\cdot v$ & 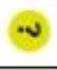 & Other bias \\
\hline
\end{tabular}

\section{Figure 3}

Risk of bias summary.

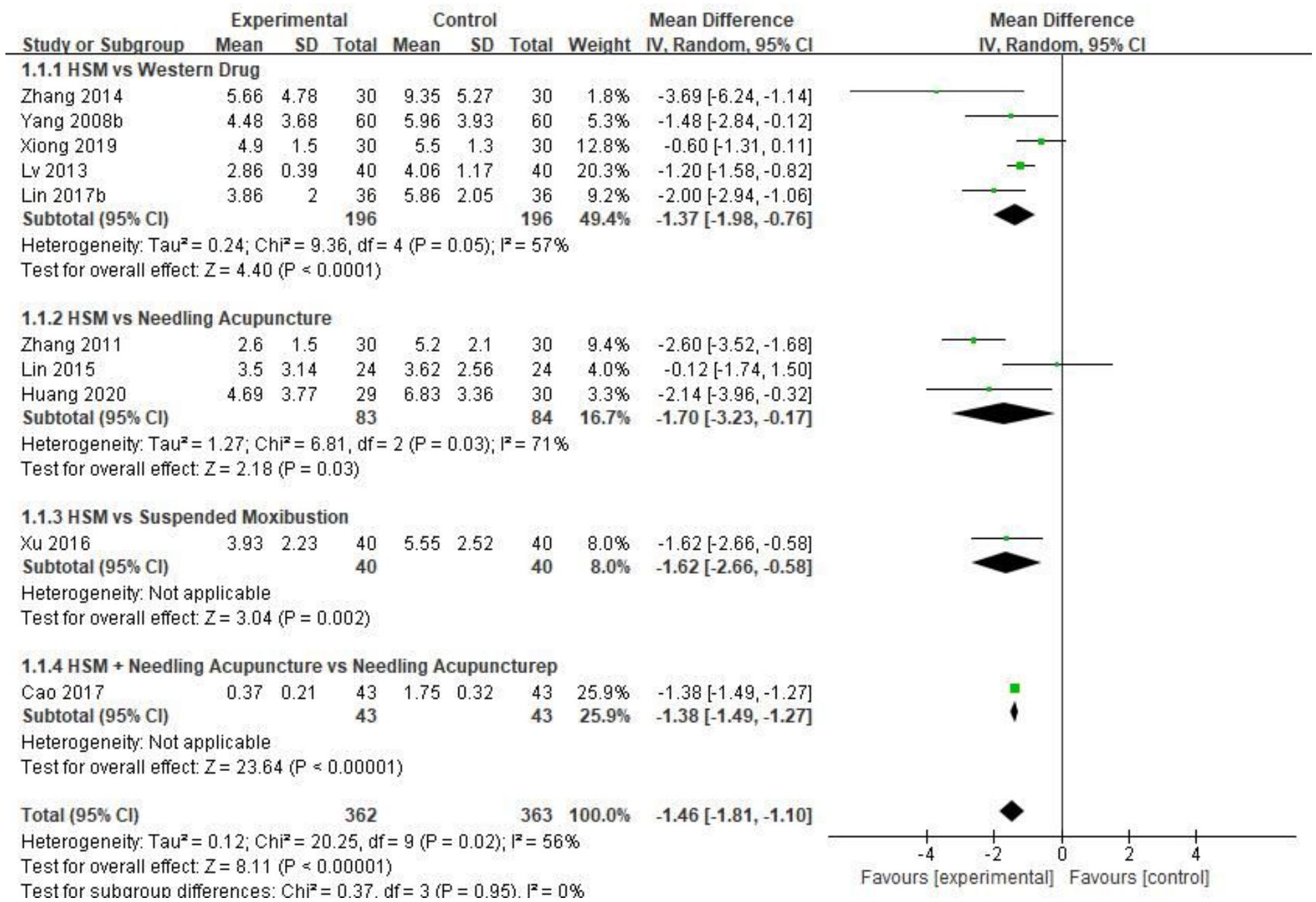

\section{Figure 4}


Forest plots of the total nasal symptom and sign score (after cessation of treatment).

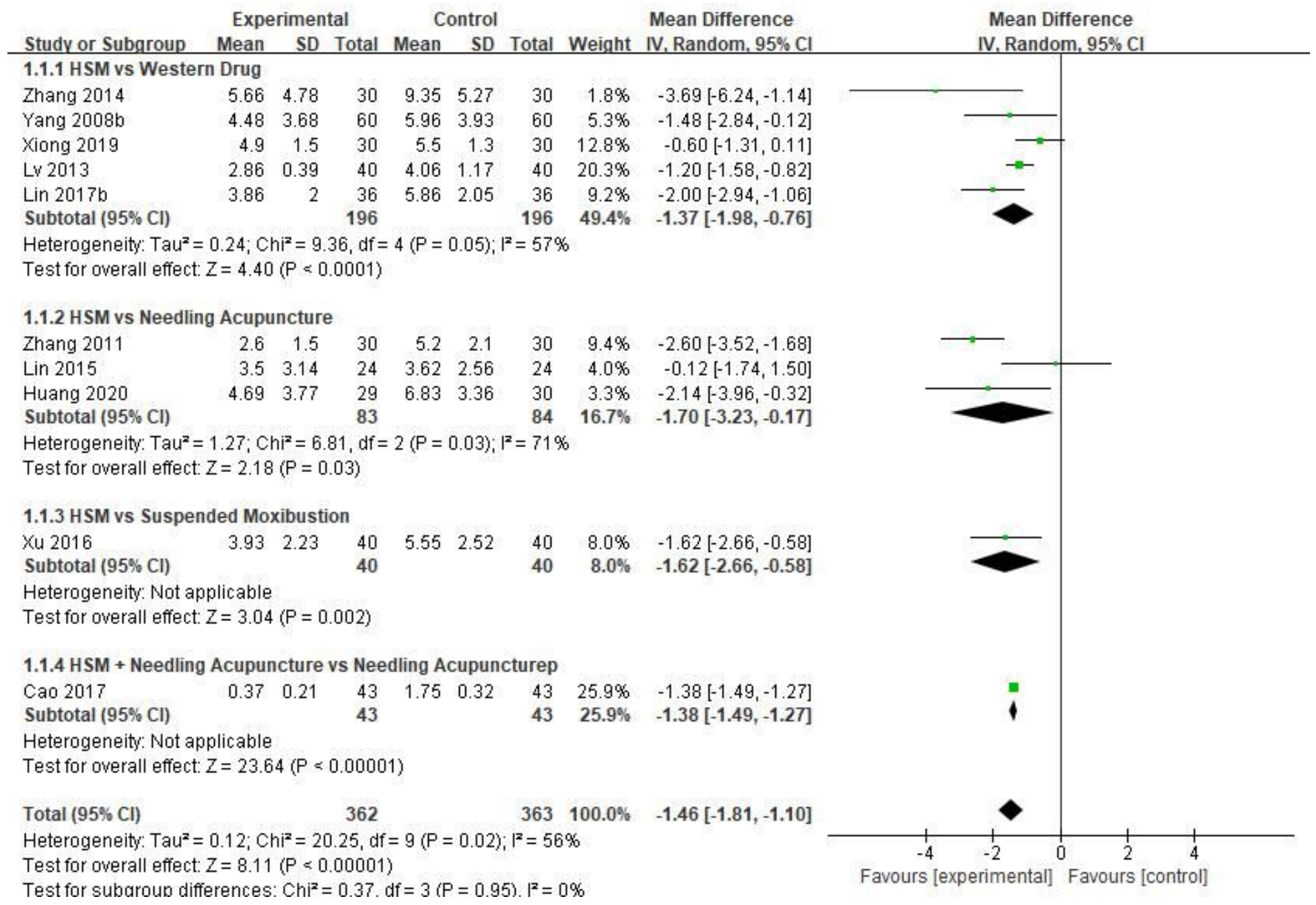

\section{Figure 4}

Forest plots of the total nasal symptom and sign score (after cessation of treatment).

\begin{tabular}{|c|c|c|c|c|c|c|c|c|c|c|c|}
\hline \multirow[b]{2}{*}{ Study or Subgroup } & \multicolumn{3}{|c|}{ Experimental } & \multicolumn{2}{|c|}{ Control } & \multirow{2}{*}{\multicolumn{3}{|c|}{$\begin{array}{cc} & \text { Mean Difference } \\
\text { Total Weight } & \text { IV, Random, } 95 \% \mathrm{Cl} \\
\end{array}$}} & \multirow{2}{*}{\multicolumn{3}{|c|}{$\begin{array}{l}\text { Mean Difference } \\
\text { IV, Random, } 95 \% \mathrm{Cl}\end{array}$}} \\
\hline & Mean & SD & Total & Mean & SD & & & & & & \\
\hline \multicolumn{12}{|c|}{ 1.2.1 HSM vs Western Drug } \\
\hline Lv 2013 & 3.86 & 1.28 & 40 & 8.06 & 2.79 & 40 & $35.8 \%$ & $-4.20[-5.15,-3.25]$ & $\rightarrow$ - & & \\
\hline Zhang 2014 & 6.54 & 4.34 & 30 & 9.91 & 4.18 & 30 & $28.2 \%$ & $-3.37[-5.53,-1.21]$ & & & \\
\hline Subtotal $(95 \% \mathrm{Cl})$ & & & 70 & & & 70 & $64.0 \%$ & $-4.06[-4.94,-3.19]$ & & & \\
\hline \multicolumn{12}{|c|}{$\begin{array}{l}\text { Heterogeneity: } \operatorname{Tau}^{2}=0.00 ; \mathrm{Chi}^{2}=0.48, \mathrm{df}=1(\mathrm{P}=0.49) ; \mathrm{I}^{2}=0 \% \\
\text { Test for overall effect: } Z=9.15(P=0.00001)\end{array}$} \\
\hline \multicolumn{12}{|c|}{ 1.2.2 HSM vs Suspended Moxibustion } \\
\hline Xu 2016 & 6.13 & 1.96 & 40 & 7.28 & 2.21 & 40 & $36.0 \%$ & $-1.15[-2.07,-0.23]$ & & & \\
\hline Subtotal $(95 \% \mathrm{Cl})$ & & & 40 & & & 40 & $36.0 \%$ & $-1.15[-2.07,-0.23]$ & & & \\
\hline \multicolumn{12}{|c|}{ Heterogeneity: Not applicable } \\
\hline \multicolumn{12}{|c|}{ Test for overall effect: $Z=2.46(P=0.01)$} \\
\hline Total $(95 \% \mathrm{Cl})$ & & & 110 & & & 110 & $100.0 \%$ & $-2.87[-5.11,-0.63]$ & & & \\
\hline \multicolumn{12}{|c|}{ 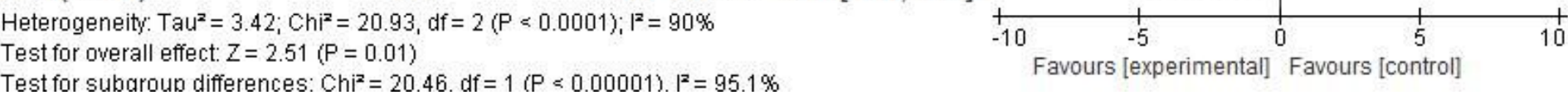 } \\
\hline
\end{tabular}

\section{Figure 5}


Forest plots of the total nasal symptom and sign score (after 3 months follow time).

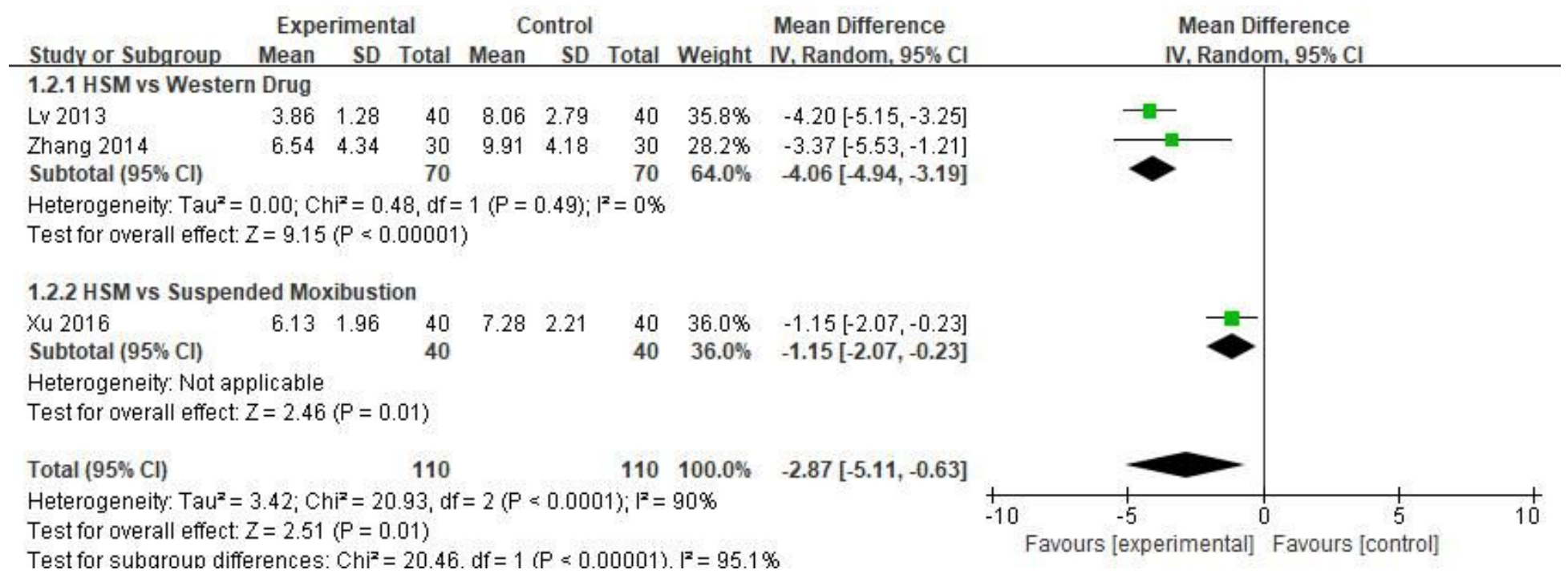

\section{Figure 5}

Forest plots of the total nasal symptom and sign score (after 3 months follow time). 
Experimental Control Odds Ratio

Odds Ratio

Study or Subgroup Events Total Events Total Weight M-H, Fixed, $95 \% \mathrm{Cl}$ 2.1.1 HSM vs Western Drug

$\begin{array}{lrrrrrr}\text { Xiong 2019 } & 23 & 30 & 22 & 30 & 10.0 \% & 1.19[0.37,3.85] \\ \text { Lin 2017b } & 30 & 36 & 24 & 36 & 7.8 \% & 2.50[0.82,7.64] \\ \text { Li 2019 } & 15 & 18 & 12 & 18 & 3.9 \% & 2.50[0.51,12.14] \\ \text { Yang 2008a } & 57 & 68 & 44 & 68 & 13.8 \% & 2.83[1.25,6.38] \\ \text { Yang 2008b } & 51 & 60 & 38 & 60 & 11.1 \% & 3.28[1.36,7.92] \\ \text { Zhang 2014 } & 26 & 30 & 19 & 30 & 4.9 \% & 3.76[1.04,13.65] \\ \text { Lv 2013 } & 35 & 40 & 25 & 40 & 6.1 \% & 4.20[1.35,13.06] \\ \text { Subtotal }(95 \% \mathrm{Cl}) & & 282 & & 282 & 57.5 \% & 2.79[1.87,4.17] \\ \text { Total events } & 237 & & 184 & & & \end{array}$

Heterogeneity: $\mathrm{Chi}^{2}=2.91, \mathrm{df}=6(\mathrm{P}=0.82) ; \mathrm{I}^{2}=0 \%$

Test for overall effect: $Z=5.01$ ( $P \leq 0.00001)$

\subsubsection{HSM vs Needling Acupuncture}

$\begin{array}{lrrrrrr}\text { Lin } 2015 & 20 & 24 & 19 & 24 & 6.2 \% & 1.32[0.31,5.65] \\ \text { Lin 2017a } & 29 & 35 & 26 & 35 & 8.7 \% & 1.67[0.52,5.34] \\ \text { Cai 2014 } & 15 & 20 & 11 & 20 & 5.3 \% & 2.45[0.64,9.39] \\ \text { Huang 2020 } & 26 & 29 & 21 & 30 & 4.2 \% & 3.71[0.89,15.48] \\ \text { Zhang 2011 } & 25 & 30 & 13 & 30 & 4.2 \% & 6.54[1.97,21.74] \\ \text { Subtotal }(95 \% \mathrm{Cl}) & & \mathbf{1 3 8} & & \mathbf{1 3 9} & \mathbf{2 8 . 5 \%} & \mathbf{2 . 7 6}[1.56,4.87]\end{array}$

Total events $\quad 115 \quad 90$

Heterogeneity: Chi $^{2}=3.88, d f=4(P=0.42) ;\left.\right|^{2}=0 \%$

Test for overall effect: $Z=3.49(P=0.0005)$

\subsubsection{HSM vs Suspended Moxibustion}

$\begin{array}{lllllll}\text { Xu } 2016 & 36 & 40 & 26 & 40 & 5.1 \% & 4.85[1.43,16.42] \\ \text { Subtotal }(95 \% \mathrm{Cl}) & & 40 & & 40 & 5.1 \% & 4.85[1.43,16.42] \\ \text { Total events } & 36 & & 26 & & & \end{array}$

Heterogeneity: Not applicable

Test for overall effect: $Z=2.53(P=0.01)$

2.1.4 HSM + Needling Acupuncture vs Needling Acupuncture

$\begin{array}{lllllll}\text { Zhu } 2020 & 36 & 40 & 29 & 40 & 5.6 \% & 3.41[0.98,11.85] \\ \text { Cao } 2017 & 41 & 43 & 36 & 43 & 3.3 \% & 3.99[0.78,20.43] \\ \text { Subtotal }(95 \% \mathrm{Cl}) & & 83 & & 83 & 8.9 \% & 3.62[1.35,9.75] \\ \text { Total events } & 77 & & 65 & & & \end{array}$

Heterogeneity: $\mathrm{Ch}^{2}=0.02, \mathrm{df}=1(\mathrm{P}=0.88) ; \mathrm{I}^{2}=0 \%$

Test for overall effect: $Z=2.55(P=0.01)$

$\begin{array}{lllllll}\text { Total }(95 \% \mathrm{Cl}) & & 543 & & 544 & 100.0 \% & 2.96[2.19,4.00] \\ \text { Total events } & 465 & & 365 & & & \end{array}$

Heterogeneity: $\mathrm{Chi}^{2}=7.77, \mathrm{df}=14(\mathrm{P}=0.90) ; \mathrm{I}^{2}=0 \%$

Test for overall effect: $Z=7.06$ ( $\mathrm{P}<0.00001$ )

Test for subaroun differences: $\mathrm{Ch}^{2}=0.93 . \mathrm{df}=3(\mathrm{P}=0.82) \cdot \mathrm{I}^{2}=0 \%$

M-H, Fixed, $95 \% \mathrm{Cl}$

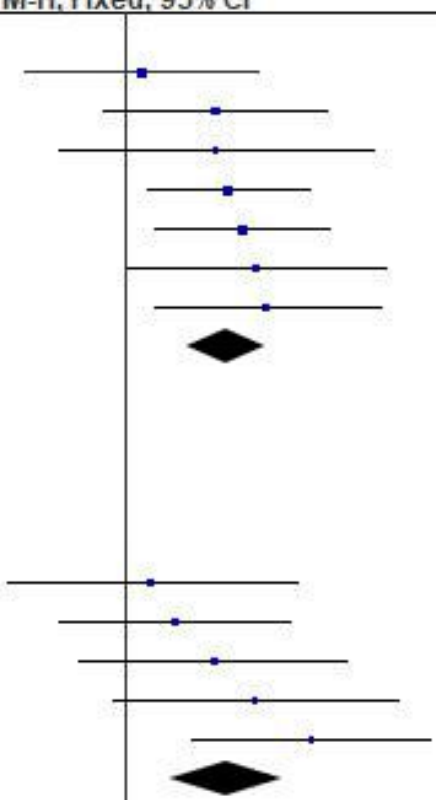

\section{Figure 6}

Forest plots of the total effective rate (after cessation of treatment). 
Study or Subgroup Events Total Events Total Weight M-H, Fixed, $95 \% \mathrm{Cl}$ 2.1.1 HSM vs Western Drug

$\begin{array}{lrrrrrr}\text { Xiong 2019 } & 23 & 30 & 22 & 30 & 10.0 \% & 1.19[0.37,3.85] \\ \text { Lin 2017b } & 30 & 36 & 24 & 36 & 7.8 \% & 2.50[0.82,7.64] \\ \text { Li 2019 } & 15 & 18 & 12 & 18 & 3.9 \% & 2.50[0.51,12.14] \\ \text { Yang 2008a } & 57 & 68 & 44 & 68 & 13.8 \% & 2.83[1.25,6.38] \\ \text { Yang 2008b } & 51 & 60 & 38 & 60 & 11.1 \% & 3.28[1.36,7.92] \\ \text { Zhang 2014 } & 26 & 30 & 19 & 30 & 4.9 \% & 3.76[1.04,13.65] \\ \text { Lv 2013 } & 35 & 40 & 25 & 40 & 6.1 \% & 4.20[1.35,13.06] \\ \text { Subtotal (95\% Cl) } & & 282 & & 282 & 57.5 \% & 2.79[1.87,4.17] \\ \text { Total events } & 237 & & 184 & & & \end{array}$

Heterogeneity: $\mathrm{Chi}^{2}=2.91, \mathrm{df}=6(\mathrm{P}=0.82) ; \mathrm{I}^{2}=0 \%$

Test for overall effect: $Z=5.01(P<0.00001)$

\subsubsection{HSM vs Needling Acupuncture}

$\begin{array}{lrrrrrr}\text { Lin } 2015 & 20 & 24 & 19 & 24 & 6.2 \% & 1.32[0.31,5.65] \\ \text { Lin 2017a } & 29 & 35 & 26 & 35 & 8.7 \% & 1.67[0.52,5.34] \\ \text { Cai 2014 } & 15 & 20 & 11 & 20 & 5.3 \% & 2.45[0.64,9.39] \\ \text { Huang 2020 } & 26 & 29 & 21 & 30 & 4.2 \% & 3.71[0.89,15.48] \\ \text { Zhang 2011 } & 25 & 30 & 13 & 30 & 4.2 \% & 6.54[1.97,21.74] \\ \text { Subtotal }(95 \% \mathrm{Cl}) & & 138 & & 139 & 28.5 \% & 2.76[1.56,4.87]\end{array}$

Total events $\quad 115 \quad 90$

Heterogeneity: $\mathrm{Ch}^{2}=3.88, \mathrm{df}=4(\mathrm{P}=0.42) ; \mathrm{I}^{2}=0 \%$

Test for overall effect: $Z=3.49(P=0.0005)$

\subsubsection{HSM vs Suspended Moxibustion}

$\begin{array}{lllllll}\text { Xu } 2016 & 36 & 40 & 26 & 40 & 5.1 \% & 4.85[1.43,16.42] \\ \text { Subtotal }(95 \% \mathrm{Cl}) & & 40 & & 40 & 5.1 \% & 4.85[1.43,16.42] \\ \text { Total events } & 36 & & 26 & & & \end{array}$

Heterogeneity: Not applicable

Test for overall effect: $Z=2.53$ ( $P=0.01$ )

2.1.4 HSM + Needling Acupuncture vs Needling Acupuncture

$\begin{array}{lllllll}\text { Zhu } 2020 & 36 & 40 & 29 & 40 & 5.6 \% & 3.41[0.98,11.85] \\ \text { Cao } 2017 & 41 & 43 & 36 & 43 & 3.3 \% & 3.99[0.78,20.43] \\ \text { Subtotal }(95 \% \mathrm{Cl}) & & 83 & & 83 & 8.9 \% & 3.62[1.35,9.75] \\ \text { Total events } & 77 & & 65 & & & \end{array}$

Heterogeneity: $\mathrm{Ch}^{2}=0.02, \mathrm{df}=1(\mathrm{P}=0.88) ; \mathrm{I}^{2}=0 \%$

Test for overall effect: $Z=2.55(P=0.01)$

$\begin{array}{lllllll}\text { Total }(95 \% \mathrm{Cl}) & & 543 & & 544 & 100.0 \% & 2.96[2.19,4.00] \\ \text { Total events } & 465 & & 365 & & & \end{array}$

Heterogeneity: $\mathrm{Chi}^{2}=7.77, \mathrm{df}=14(\mathrm{P}=0.90) ; \mathrm{I}^{2}=0 \%$

Test for overall effect: $Z=7.06$ ( $\mathrm{P}<0.00001$ )

Test for subaroun differences: $\mathrm{Chi}^{2}=0.93 . \mathrm{df}=3(\mathrm{P}=0.82) \cdot \mathrm{I}^{2}=0 \%$

\section{Figure 7}

Forest plots of the total effective rate (after cessation of treatment). 
Experimental Control
Events Total Events Total Weight
M-H, Fixed, $95 \% \mathrm{Cl}$

Study or Subgroup Events

2.2.1 HSM vs Western Drug

$\begin{array}{lrrrrrr}\text { LV 2013 } & 30 & 40 & 12 & 40 & 12.5 \% & 7.00[2.62,18.74] \\ \text { Yang 2008a } & 52 & 68 & 25 & 68 & 24.5 \% & 5.59[2.65,11.79] \\ \text { Yang 2008b } & 44 & 60 & 19 & 60 & 21.1 \% & 5.93[2.69,13.07] \\ \text { Zhang 2014 } & 20 & 30 & 10 & 30 & 13.9 \% & 4.00[1.37,11.70] \\ \text { Subtotal }(95 \% \mathrm{Cl}) & & 198 & & 198 & 71.9 \% & 5.63[3.65,8.69] \\ \text { Total events } & 146 & & 66 & & & \end{array}$

Heterogeneity: $\mathrm{Chi}^{2}=0.59, \mathrm{df}=3(\mathrm{P}=0.90) ; \mathrm{I}^{2}=0 \%$

Test for overall effect: $Z=7.81$ ( $P<0.00001)$

2.2.2 HSM vs Needling Acupuncture

$\begin{array}{lcccccc}\text { Huang } 2020 & 24 & 29 & 15 & 30 & 10.6 \% & 4.80[1.45,15.94] \\ \text { Subtotal }(95 \% \mathrm{Cl}) & & 29 & & 30 & 10.6 \% & 4.80[1.45,15.94] \\ \text { Total events } & 24 & & 15 & & & \end{array}$

Heterogeneity: Not applicable

Test for overall effect: $Z=2.56(P=0.01)$

2.2.3 HSM vs Suspended Moxibustion

Xu $2016 \quad 26 \quad 40$

Subtotal $(95 \% \mathrm{Cl})$

Total events 26

Heterogeneity: Not applicable

Test for overall effect: $Z=3.06$ ( $P=0.002$ )

Total $(95 \% \mathrm{Cl})$

267

12

$40 \quad 17.5 \% \quad 4.33[1.70,11.07]$

$40 \quad 17.5 \% \quad 4.33[1.70,11.07]$

12

Total events

$196 \quad 93$

Heterogeneity: $\mathrm{Ch}^{2}=0.87, \mathrm{df}=5(P=0.97) ; \mathrm{I}^{2}=0 \%$

Test for overall effect: $Z=8.76$ ( $P=0.00001)$

Test for subaroun differences: $\mathrm{Chi}^{2}=0.28 \mathrm{df}=2(\mathrm{P}=0.87) \cdot \mathrm{I}^{2}=0 \%$

$268 \quad 100.0 \% \quad 5.31[3.66,7.72]$

$268 \quad 100.0 \% \quad 5.31[3.66,7.72]$

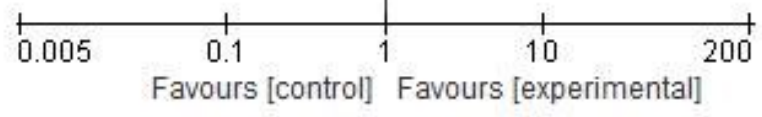

\section{Figure 7}

Forest plots of the total effective rate (after 3 months follow time). 
Experimental Control Odds Ratio

Study or Subgroup Events Total Events Total Weight M-H, Fixed, 95\% C

M-H, Fixed, $95 \% \mathrm{Cl}$

2.2.1 HSM vs Western Drug

$\begin{array}{lrrrrrr}\text { Lv 2013 } & 30 & 40 & 12 & 40 & 12.5 \% & 7.00[2.62,18.74] \\ \text { Yang 2008a } & 52 & 68 & 25 & 68 & 24.5 \% & 5.59[2.65,11.79] \\ \text { Yang 2008b } & 44 & 60 & 19 & 60 & 21.1 \% & 5.93[2.69,13.07] \\ \text { Zhang 2014 } & 20 & 30 & 10 & 30 & 13.9 \% & 4.00[1.37,11.70] \\ \text { Subtotal }(95 \% \mathrm{Cl}) & & 198 & & 198 & 71.9 \% & 5.63[3.65,8.69] \\ \text { Total events } & 146 & & 66 & & & \end{array}$

Heterogeneity: $\mathrm{Ch}^{2}=0.59, \mathrm{df}=3(\mathrm{P}=0.90) ;\left.\right|^{2}=0 \%$

Test for overall effect: $Z=7.81$ ( $P<0.00001)$

2.2.2 HSM vs Needling Acupuncture

$\begin{array}{lcccrrr}\text { Huang } 2020 & 24 & 29 & 15 & 30 & 10.6 \% & 4.80[1.45,15.94] \\ \text { Subtotal }(95 \% \mathrm{Cl}) & & 29 & & 30 & \mathbf{1 0 . 6 \%} & 4.80[1.45,15.94] \\ \text { Total events } & 24 & & 15 & & & \end{array}$

Heterogeneity: Not applicable

Test for overall effect: $Z=2.56(P=0.01)$

2.2.3 HSM vs Suspended Moxibustion

$\begin{array}{lcccccc}\text { Xu } 2016 & 26 & 40 & 12 & 40 & 17.5 \% & 4.33[1.70,11.07] \\ \text { Subtotal }(95 \% \mathrm{Cl}) & & 40 & & 40 & \mathbf{1 7 . 5 \%} & 4.33[1.70,11.07] \\ \text { Total events } & 26 & & 12 & & & \end{array}$

Heterogeneity: Not applicable

Test for overall effect: $Z=3.06(P=0.002)$

Total $(95 \% \mathrm{Cl})$

267

$268 \quad 100.0 \%$

$5.31[3.66,7.72]$

Total events $196 \quad 93$

Heterogeneity: $\mathrm{Ch}^{2}=0.87, \mathrm{df}=5(\mathrm{P}=0.97) ; \mathrm{I}^{2}=0 \%$

Test for overall effect: $Z=8.76$ ( $P=0.00001)$

Test for subaroun differences: $\mathrm{Chi}^{2}=0.28 . \mathrm{df}=2(\mathrm{P}=0.87) \cdot \mathrm{I}^{2}=0 \%$

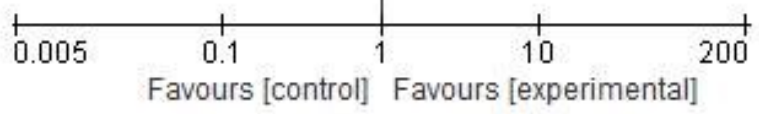

Figure 7

Forest plots of the total effective rate (after 3 months follow time).

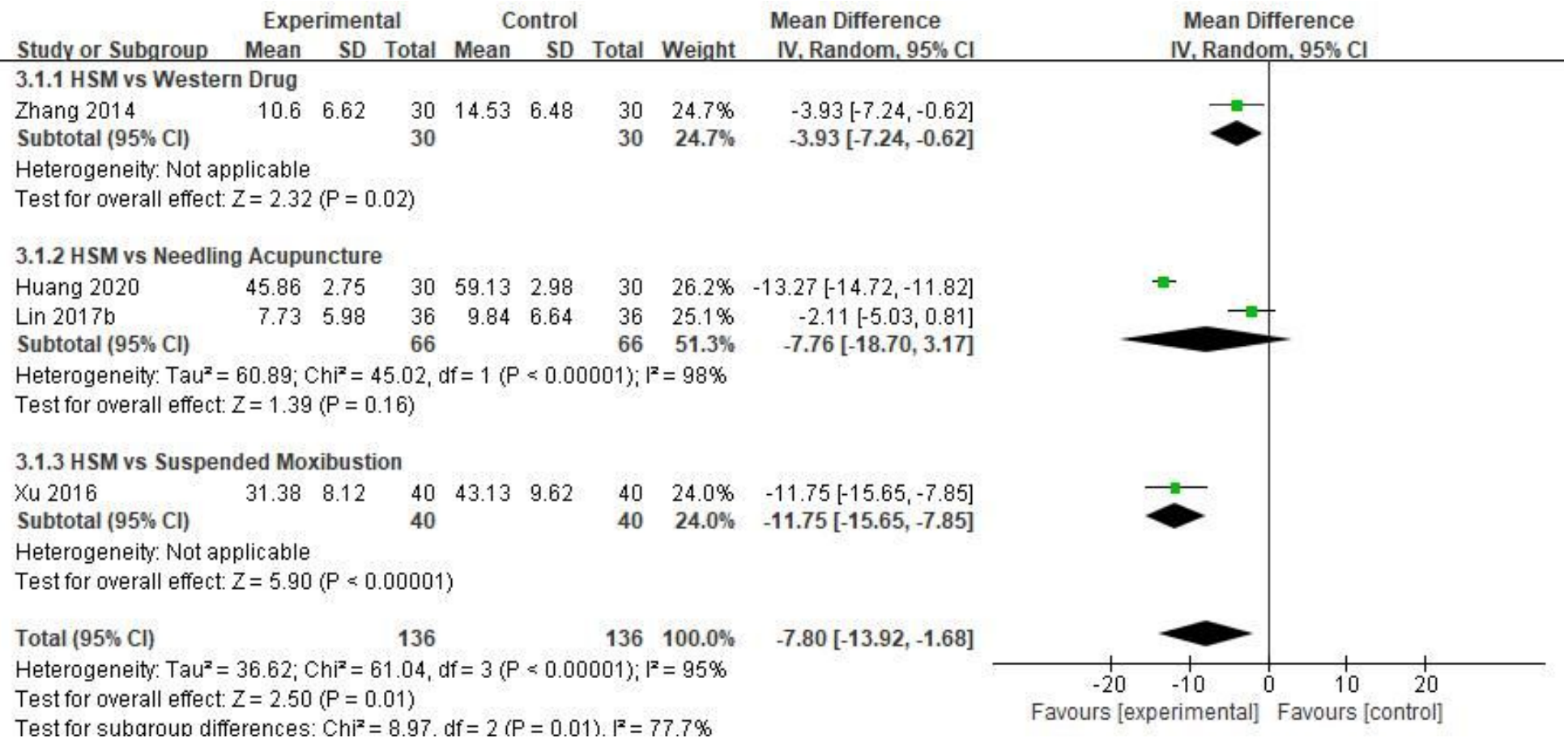

Figure 8 
Forest plots of RQLQ (after cessation of treatment).

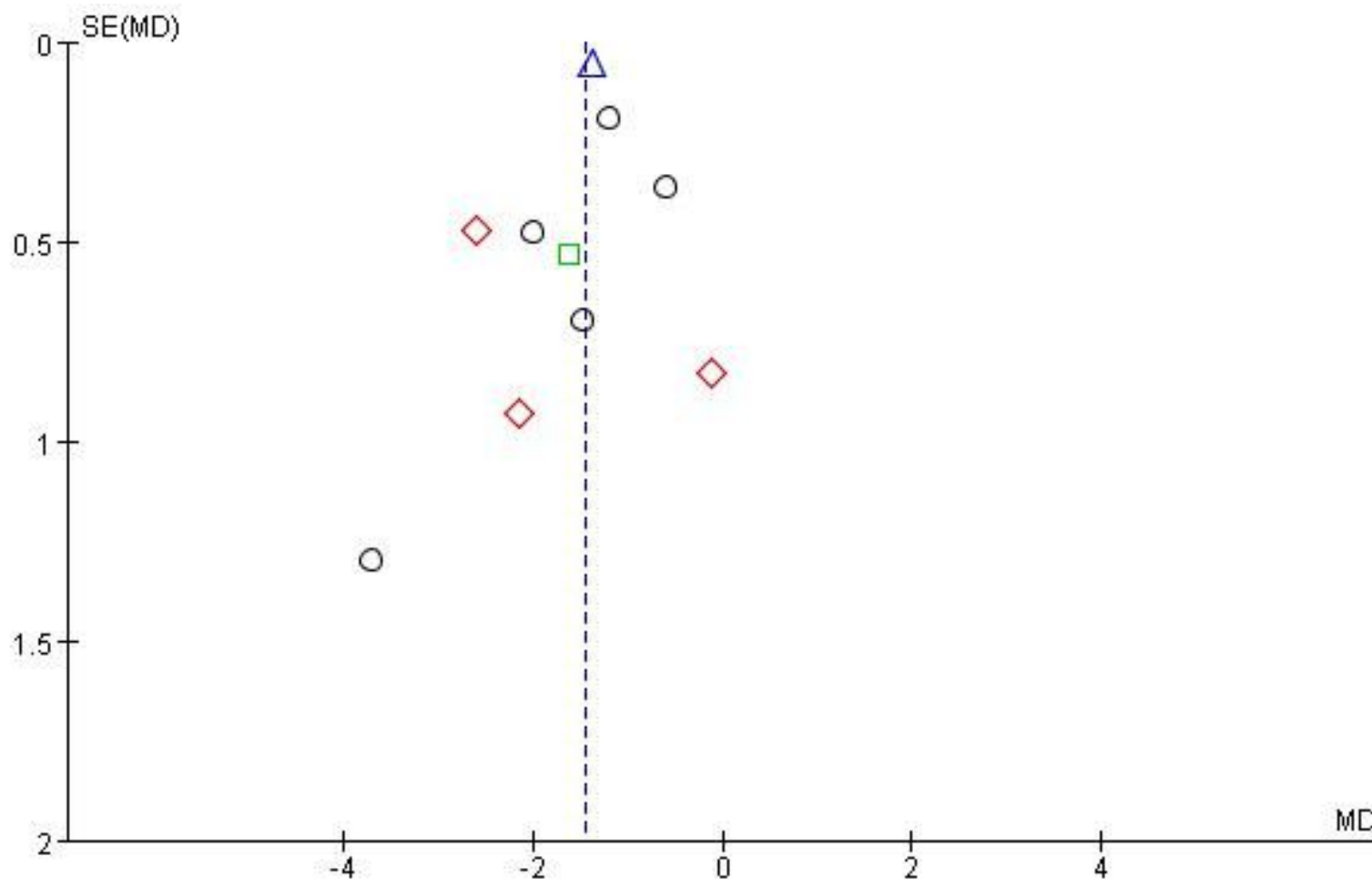

Subgroups

HSM vs Western Drug

$\checkmark$ HSM vs Needling Acupuncture

$\square$ HSM vs Suspended Moxibustion

$\triangle \mathrm{HSM}+$ Needling Acupuncture vs Needling Acupuncturep

\section{Figure 9}

Funnel plot of the total nasal symptom and sign score. 


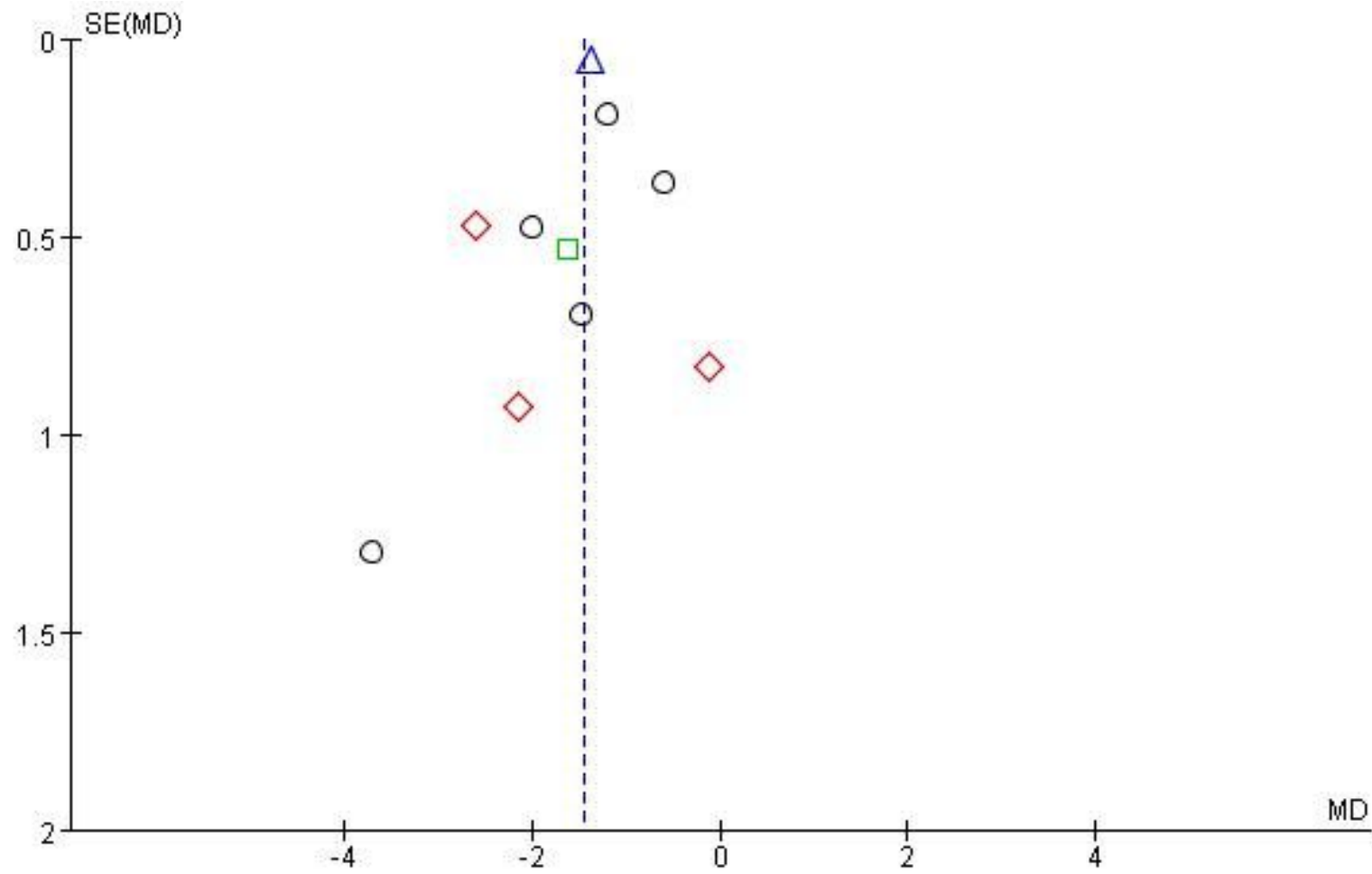

\section{Subgroups}

HSM vs Western Drug

$\checkmark$ HSM vs Needling Acupuncture

$\square$ HSM vs Suspended Moxibustion

$\triangle \mathrm{HSM}+$ Needling Acupuncture vs Needling Acupuncturep

\section{Figure 9}

Funnel plot of the total nasal symptom and sign score.

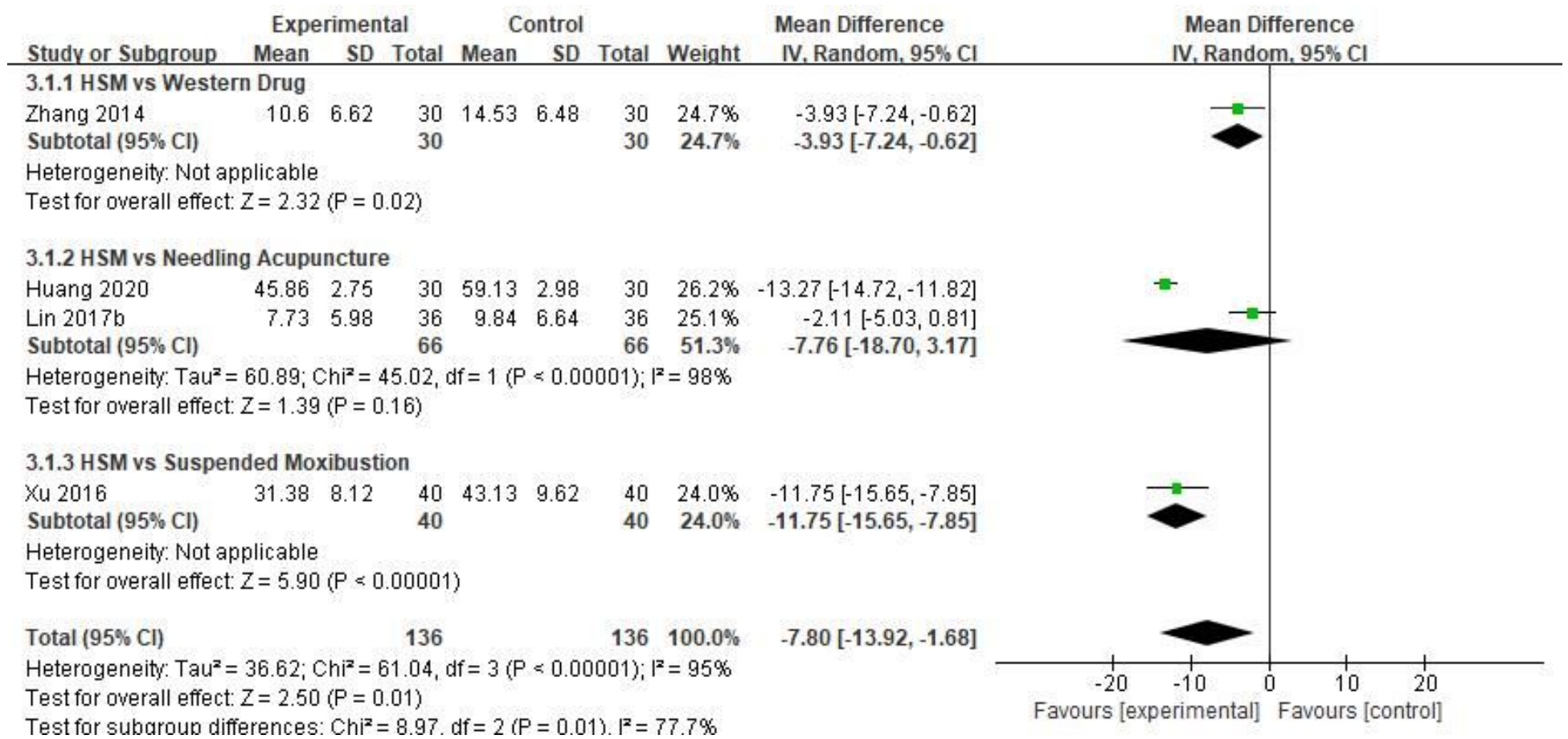

Figure 9 
Forest plots of RQLQ (after cessation of treatment).

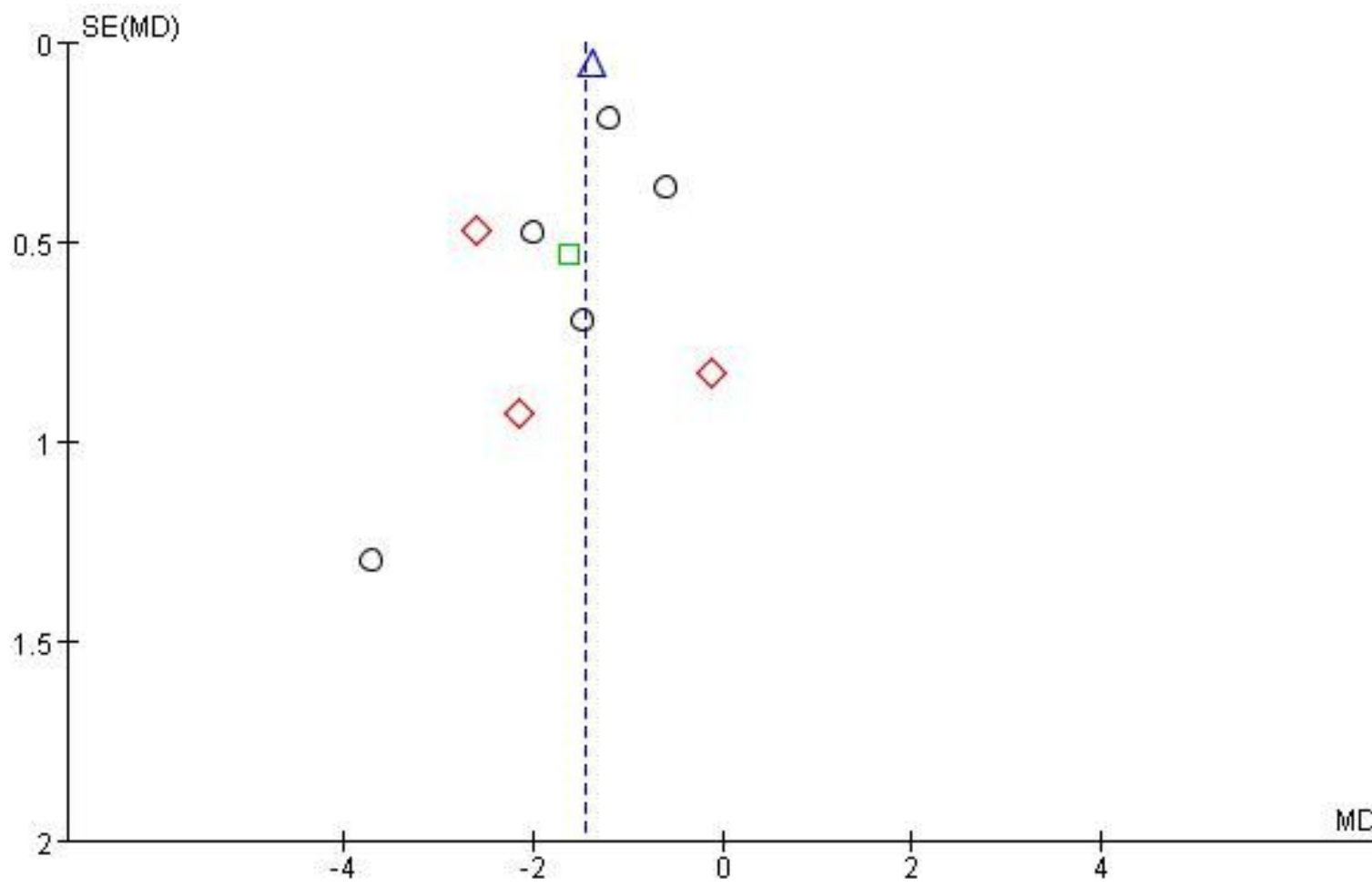

Subgroups

HSM vs Western Drug

$\checkmark$ HSM vs Needling Acupuncture

$\square$ HSM vs Suspended Moxibustion

$\triangle \mathrm{HSM}+$ Needling Acupuncture vs Needling Acupuncturep

Figure 10

Funnel plot of the total nasal symptom and sign score. 


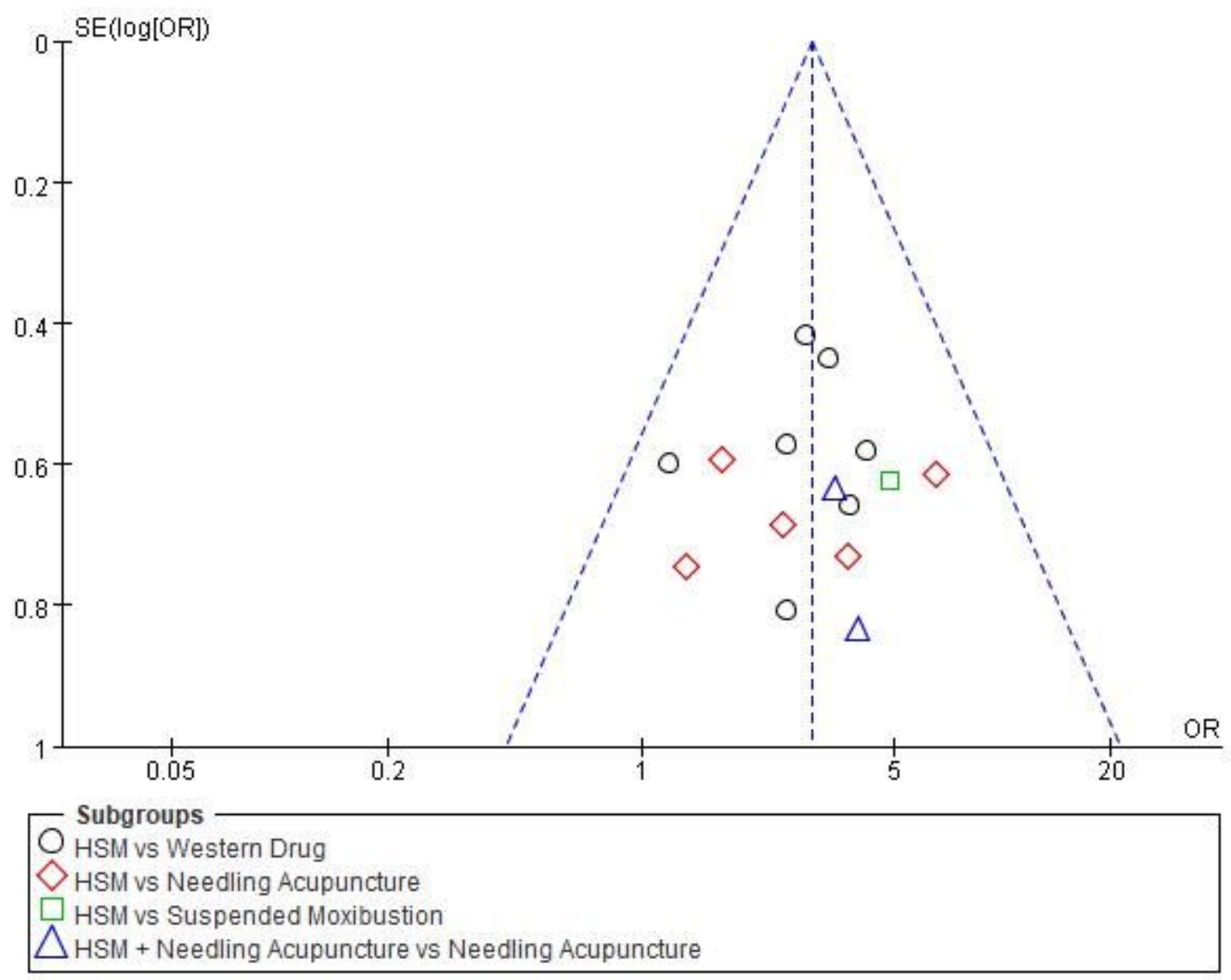

Figure 10

Funnel plot of the total effective rate. 


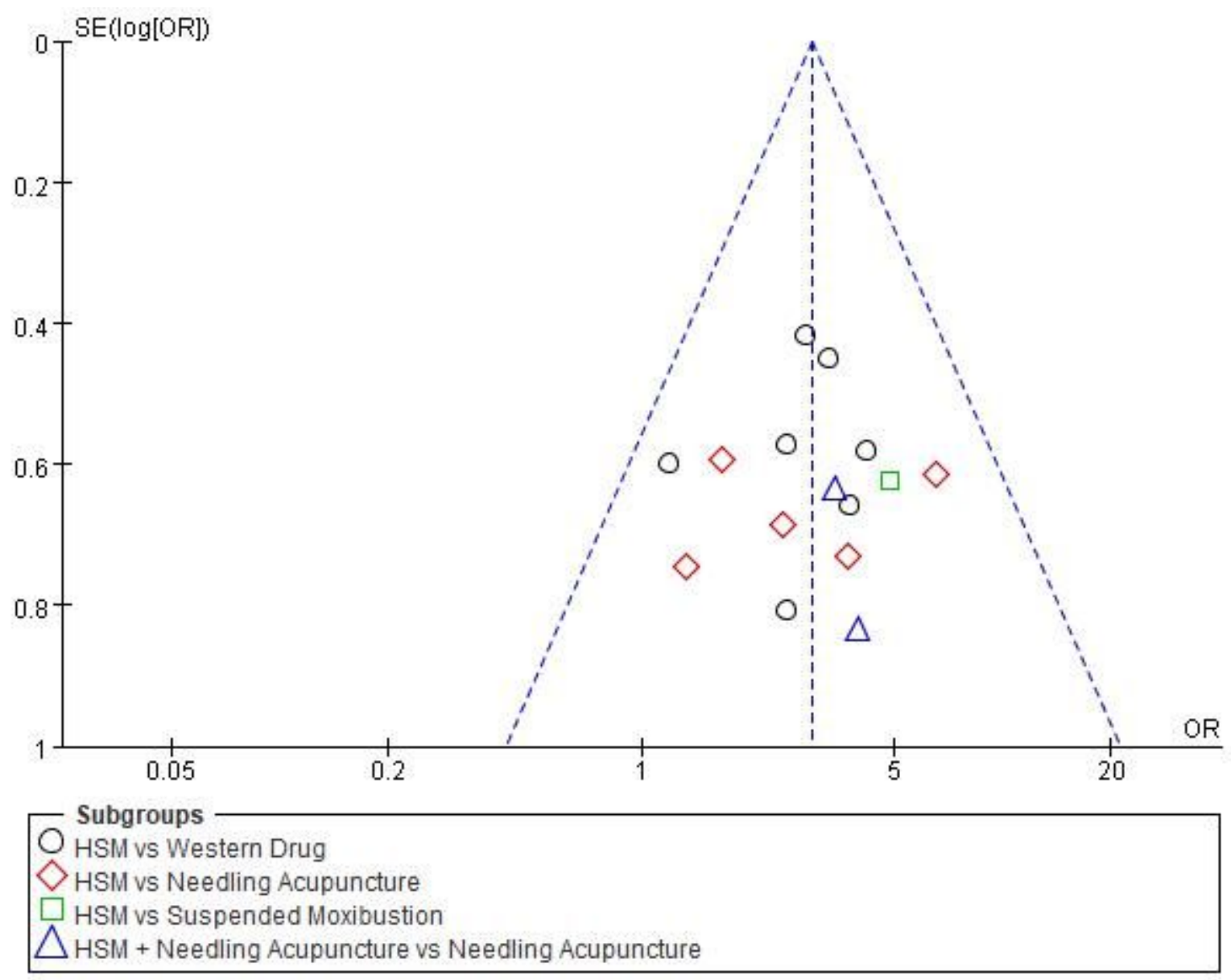

Figure 11

Funnel plot of the total effective rate. 